\title{
Subduction Zone Metamorphic Pathway for Deep Carbon Cycling: II. Evidence from HP/UHP Metabasaltic Rocks and Ophicarbonates
}

Nathan C. Collins ${ }^{1}$, Gray E. Bebout ${ }^{1}$, Samuel Angiboust ${ }^{2}$, Philippe Agard ${ }^{3}$, Marco Scambelluri ${ }^{4}$, Laura Crispini ${ }^{4}$, Timm John ${ }^{5}$

${ }^{1}$ Department of Earth and Environmental Sciences, Lehigh University, Bethlehem, Pennsylvania, 18015, U.S.A. (corresponding author; telephone: 610-758-5831; FAX: 610-758-3677; e-mail: geb0@ lehigh.edu)

${ }^{2}$ GeoForschungsZentrum (GFZ), Telegrafenberg, D-14473 Potsdam, Germany ${ }^{3}$ ISTEP, Université Paris 06-UPMC, UMR CNRS 7193, 4 place Jussieu, F-75005, Paris, France ${ }^{4}$ Dip.Te.Ris Università degli Studi di Genova Via Balbi, 5 - 16126 Genova, Italy ${ }^{5}$ Institut für Geologische Wissenschaften, Malteserstrasse 74-100, D-12249 Berlin, Germany 


\section{Abstract}

Exposures of low-grade metabasalts and ophicarbonates in the Northern Apennines, and their high- and ultrahigh-pressure metamorphic equivalents in the Western and Ligurian Alps and Tianshan (representing an overall peak $P-T$ range of $\sim 0.2-3.0 \mathrm{GPa}, 200-610^{\circ} \mathrm{C}$ ), allow investigation of the effects of prograde metamorphic devolatilization, and other fluid-rock interactions, on degrees of retention and isotopic evolution of $\mathrm{C}$ in subducting oceanic crust and associated mantle rocks. Such work can inform models of C cycling at convergent margins, helping constrain the efficiency of return of initially subducted $\mathrm{C}$ via arc volcanism and the fraction of this subducted $\mathrm{C}$ entering the deeper mantle beyond arcs.

In the metabasaltic rocks, the preservation of finely disseminated carbonate with $\delta^{13} \mathrm{C}$ overlapping that of seafloor-altered protoliths, and the minimal mineralogical evidence of decarbonation, indicate large degrees of carbonate retention in this suite extending to UHP conditions similar to those beneath modern volcanic fronts. For many of the metabasalts, the $\delta^{18} \mathrm{O}$ of this carbonate can be explained by closed-system equilibration with silicate phases (e.g., garnet, clinopyroxene) during HP/UHP metamorphism. Larger volumes of carbonate preserved in interpillow regions and as breccia-filling largely escaped decarbonation, showing little or no evidence for reaction with adjacent metabasalt. Calculated devolatilization histories demonstrate that, in a closed-system model, carbonate in metabasaltic rocks can largely be preserved to depths approaching those beneath volcanic fronts $(80-90 \mathrm{~km})$. Modeling of open-system behavior indicates that episodic infiltration of such rocks by $\mathrm{H}_{2} \mathrm{O}$-rich fluids would have greatly enhanced decarbonation. Trends in $\mathrm{O}-\mathrm{C}$ isotope composition of carbonate in some metabasaltic suites likely reflect effects of infiltration by externally-derived fluid with or without resulting decarbonation. Carbonated ultramafic rocks similarly show little mineralogical evidence for decarbonation, consistent with calculated reaction histories, and have $\delta^{13} \mathrm{C}$ largely overlapping that of seafloor equivalents. However, the high-grade ophicarbonates show more restricted ranges in $\delta^{18} \mathrm{O}$ consistent with some control by infiltrating fluids, likely during subduction.

This combination of field, petrographic, and isotopic evidence, together with calculated decarbonation histories, is consistent with minimal loss of $\mathrm{CO}_{2}$ from these rocks via decarbonation during forearc metamorphism. Combining our results with those of Cook-Kollars et al. (2014; Chemical Geology) for associated W. Alps metasedimentary rocks, we suggest that the majority of the $\mathrm{CO}_{2}$ (perhaps $80-90 \%$, considering the full range of rock types) could be 
retained through forearcs in more intact volumes of subducting sediment, basalt, and

72 ophicarbonate experiencing closed- or limited open-system conditions. Deep in forearcs and

73 beneath arcs, decarbonation (and also carbonate dissolution) could be enhanced in shear zones

74 and highly fractured volumes experiencing larger fluid flux in part from dehydrating sub-crustal

75 ultramafic rocks in slabs. Degrees of C loss by decarbonation, carbonate dissolution, and partial

76 melting should be particularly significant as the subducting sections experience heating to $>600$

$77{ }^{\circ} \mathrm{C}$ at depths of 80-120 km (i.e., approximately at depths beneath arcs).

\section{Introduction}

Understanding of deep-Earth C flux in subducting oceanic lithosphere and sediments is crucial to modeling volatiles contributions to volcanic arcs, evolution of the atmosphere, and long-term degassing or regassing of the mantle (Berner et al., 1983; Berner, 1999; Zhang and Zindler, 1993; Marty and Toltskhin, 1998; Dasgupta and Hirschmann, 2010; Van Der Meer et al., 2014). Current understanding of the degrees of $\mathrm{C}$ retention to great depths in subduction zones is largely based on studies of volcanic gas output in comparison with subduction zone inputs, the latter based on knowledge of seafloor lithologies (see Hilton et al., 2002). Additional understanding has come from theoretical and experimental studies of phase stabilities in subducting oceanic lithologies (e.g., Kerrick and Connolly, 1998, 2001a,b; Molina and Poli, 2000; Gorman et al., 2006; Poli et al., 2009; Tsuno and Dasgupta, 2011; Schmidt and Poli, 2014;

Cook-Kollars et al., 2014). There is general agreement that the behavior of $\mathrm{C}$ (and other major volatiles) along the subduction-zone metamorphic pathway must be taken into account when assessing long-term Earth degassing and atmosphere evolution (Bebout, 1995, 2007b, 2014; Javoy, 1998; Kerrick, 2001; Dasgupta and Hirschmann, 2010; Dasgupta, 2013; Cook-Kollars et al., 2014). However, there has been relatively little petrologic and geochemical study of decarbonation, and other mechanisms of $\mathrm{C}$ mobilization, in high-pressure (HP) and ultrahigh- 
pressure (UHP) metamorphic suites representing the pathway taken by appropriate rock types subducting through forearcs and to beneath arcs.

A number of studies have considered global $\mathrm{C}$ subduction flux through comparison of subduction zone inputs in sediments, altered oceanic crust, and hydrated ultramafic rocks and subduction outputs in volcanic gases (e.g. Bebout 1995, 2007b, 2014; Hilton et al., 2002; Jarrard, 2003; Dasgupta and Hirschmann, 2010; Dasgupta, 2013). The complexity and related uncertainty of these estimates are evident in the large ranges of published input flux estimates presented in Table 1 (also see Cook-Kollars et al., 2014). The combination of the uncertainties in the inputs and outputs results in a wide range in the estimates of volcanic arc return efficiency (16-80\% arc return of the $\mathrm{C}$ entering trenches; Table 1). Some studies of arc volcanic $\mathrm{CO}_{2}$ emissions have estimated the efficiencies of volcanic return of deeply subducted $\mathrm{C}$ for individual margins (e.g., Hilton et al., 2002; Shaw et al., 2003; Zimmer et al., 2004; de Leeuw et al., 2007; Marin-Ceron et al., 2010; Halldorsson et al., 2013). To examine the sourcing of $\mathrm{C}$ flux measured in volcanic gases, de Leeuw et al. (2007) compared C inputs measured by Li and Bebout (2005) for sediments outboard of the Central America trench. They suggested that contributions of sedimentary $\mathrm{C}$ alone could account for the measured output of gases and estimated a $\mathrm{C}$ return of $12-18 \%$ in Costa Rica and $29 \%$ in El Salvador. The lack of a contribution of volatiles from subducting oceanic crust to arc volcanic gases was also suggested by Sano et al. (2001; Sano and Williams, 1996), Hilton et al. (2002), and Zimmer et al. (2004). However, it could be difficult to distinguish the contributions of $\mathrm{CO}_{2}$ from carbonate sediment and from carbonate in altered oceanic crust based on the $\mathrm{CO}_{2} /{ }^{3} \mathrm{He}$ and $\delta^{13} \mathrm{C}$ of the volcanic gases (see House et al., 2014). Theoretical studies have calculated phase stabilities for sediments, oceanic crust, and ultramafic lithologies associated with inputs into subduction zones (Molina and Poli, 2000; 
119 Kerrick and Connolly, 1998, 2001a,b; Wei and Powell, 2003; Wei et al., 2003; Proyer, 2003;

120 Connolly, 2005; Gorman et al., 2006; Cook-Kollars et al., 2014). Kerrick and Connolly (2001a)

121 calculated mineral assemblages and volatiles concentrations for a wide range of sediment

122 compositions, along subduction-zone $P-T$ paths for modern margins, examining a closed-system

123 model where decarbonation in subducting sediments allows $\mathrm{CO}_{2}$ to be expelled from sediments

124 without the influence of infiltrating, externally-derived $\mathrm{H}_{2} \mathrm{O}$ fluids. In contrast, Gorman et al.

125 (2006) investigated "open" system behavior in which crustal material, and sub-crustal slab

126 ultramafic rocks, can contribute $\mathrm{H}_{2} \mathrm{O}$-rich fluids to overlying sediments and basalts, thus driving

127 decarbonation reactions. It is conceivable that the $\mathrm{H}_{2} \mathrm{O}$-rich fluids emanating from the upper

128 mantle in subducting slabs contain small amounts of $\mathrm{CO}_{2}$ (or other $\mathrm{C}$ fluid species), depending

129 on the $\mathrm{C}$ content of the hydrated ultramafic rocks (see Kerrick and Connolly, 1998; discussion by

130 Alt et al., 2013). The coupling of external fluid-ingress and decarbonation within subducting

131 slabs has been described in some studies of HP rocks (e.g., John et al., 2008; Ague and Nicolescu,

132 2014), and the opposite has also been described, with carbonation occurring along major intra-

133 slab fluid conduits (Beinlich et al., 2010; John et al., 2012). Closed- and open-system scenarios

134 can produce drastically differing degrees of forearc devolatilization (Gorman et al., 2006; see the

135 discussion by Cook-Kollars et al., 2014), pointing to the need for "ground-truthing" by detailed

136 study of devolatilization and fluid mobility in exposures of HP/UHP-metamorphosed oceanic

137 lithologies.

138 Few studies have investigated the degrees of deep retention of $\mathrm{C}$, as carbonate or reduced $\mathrm{C}$

139 (the latter largely metamorphosed organic matter), in appropriate lithologies (sediment, oceanic

140 crust, and carbonated ultramafic rocks) and over the wide range of $P$ - $T$ conditions representative

141 of trench to subarc metamorphism in subduction zones. The studies to date, mostly focusing on 
142 metasedimentary suites, have indicated substantial retention of $\mathrm{C}$ and other volatiles during the

143 relatively cool metamorphic conditions experienced at $<40 \mathrm{~km}$ depths in most forearcs (see

144 Bebout, 1995; Bebout and Fogel, 1992; Sadofsky and Bebout, 2003) and extending to depths

145 approaching those beneath volcanic fronts (e.g., in the HP/UHP units in the Italian Alps; Cook-

146 Kollars et al., 2014; also see Busigny et al., 2003; Bebout et al., 2013). Greater degrees of

147 devolatilization and associated volatiles losses, including $\mathrm{C}$ isotope shifts in reduced $\mathrm{C}$, occur in

148 metasedimentary rocks along relatively warm subduction-zone $P$ - $T$ paths, such as those

149 represented by the higher-grade units of the Catalina Schist (see Bebout, 1995; Bebout and Fogel,

150 1992). Other field and petrologic studies provide descriptions for UHP carbonate rocks at

151 individual localities without detailed work evaluating extents of decarbonation and related

152 isotopic shifts (e.g. Becker and Altherr, 1992; Kato et al., 1997; Zheng et al., 2003; Castelli et al.,

153 2007; van der Straaten et al., 2008, 2012; Proyer et al., 2014; Lu et al., 2014). The smaller

154 number of studies of HP/UHP metabasaltic rocks conducted at single localities, or over small

155 ranges in grade (prehnite-pumpellyite to blueschist facies), have similarly indicated retention of

$156 \mathrm{C}$ in subducting oceanic crust, with little or no isotopic shift, across metamorphic grades

157 (Cartwright and Barnicoat, 1999, 2003; Miller et al., 2001). This points to the need for more

158 thorough study of $\mathrm{C}$ loss from altered oceanic crust (AOC) and ultramafic rocks, the latter

159 representing either peridotite hydrated and carbonated on the seafloor or sub-crustal slab

160 ultramafic rocks hydrated and carbonated during slab bending and associated faulting and deep

161 infiltration by seawater (see discussion of faulting and infiltration process by Ranero et al., 2005).

162 The decarbonation and overall C loss history of deeply subducting AOC is particularly key to

163 understanding subduction $\mathrm{C}$ cycling as this lithology could convey one-half to two-thirds of the

164 subduction C input inventory into trenches (Table 1; see Dasgupta and Hirschmann, 2010; 
165 Dasgupta, 2013; Cook-Kollars et al., 2014). The C subduction input in carbonated ultramafic

166

167

168

169

170

171

172

173

174

175

176

177

178

179

180

181

182

183

184

185

186

187

rocks is likely far smaller, but still a significant flux (see Alt et al., 2013; Table 1).

In this study, we investigated the effects of prograde metamorphism, devolatilization, and other fluid-rock interactions on the retention and isotopic evolution of $\mathrm{C}$ in $\mathrm{AOC}$ and hydrated and carbonated ultramafic rocks that experienced HP/UHP metamorphism over a wide range of estimated peak temperatures and pressures $\left(\sim 0.2-3.0 \mathrm{GPa}, 200-610^{\circ} \mathrm{C}\right)$. The work focused mostly on exposures in the Italian (and French) Alps, the Ligurian Alps, and the northern Apennines containing intact ophiolitic sequences and related cover sediments that experienced widely varying degrees of HP/UHP metamorphism (see Fig. 1A; geographic coordinates are provided in Supplementary Table 1). The rocks in the Western Alps are known to have experienced smaller amounts of exhumation-related overprinting than exposures of similar rocks in the Eastern and Central Alps and in most other HP/UHP metamorphic terrains around the world (Platt, 1986; Desmons et al., 1999a,b; Jolivet et al., 2003; Zheng, 2012), affording a more thorough assessment of prograde metamorphic devolatilization history (see Bebout, 2007a; Bebout et al., 2013). In this paper, we provide a smaller dataset for carbonate in veins, and as finely disseminated carbonate, in well-studied eclogites in the Tianshan, including eclogites sampled across the envelopes of veins interpreted to be significant intraslab fluid conduits and eclogites that were rehydrated to blueschist along the plate interface during their exhumation (Zack and John, 2007; van der Straaten et al., 2008, 2012; Beinlich et al., 2010; John et al., 2012). We integrate field and petrologic observations, theoretical calculations of devolatilization history (using the Perple_X software; Connolly, 2005), and O and C isotope data for these rocks, largely focusing on carbonate (and decarbonation history) but with some attention paid to the minor reduced $\mathrm{C}$ that could reside in the metabasalts. A companion paper (Cook-Kollars et al., 2014) 
188 examined the record of devolatilization, and $\mathrm{C}$ release and mobility, in the metasedimentary

189 rocks exposed at most of the localities in the Italian and French Alps investigated in our study

190 (Cottian Alps and at Lago di Cignana).

191

192

\section{Geologic Setting}

The NW Italian and French Alps contain an abundance of Jurassic ophiolitic fragments that

194 were formed $\sim 160-170 \mathrm{Ma}$ in the paleo-Tethys Ocean and rapidly subducted ( $\sim 3$ to $5 \mathrm{Ma})$ to

195 peak metamorphic conditions 45 Ma (Gebauer et al., 1997; Rubatto and Hermann, 2001, 2003).

196 This region is of particular interest as it preserves slices of intact ophiolitic sequences

197 metamorphosed over a wide range of peak $P-T$ conditions (see Fig. 1), showing relatively small

198 degrees of retrogression due to exhumation (Rubatto and Hermann, 2001; Parrish et al., 2006)

199 and lithologically resembling modern Atlantic-type (slow-spreading rate) oceanic lithosphere

200 (Lagabrielle and Cannat, 1990; Tricart and Lemoine, 1991; Cannat et al., 1997).

201 Internal Ligurides, Sestri Voltaggio Zone and Voltri Massif, Italy. Several units in the

202 Internal Liguride units of the Northern Apennines, and of the blueschist to eclogite facies Sestri

203 Voltaggio Zone and Voltri Massif, were sampled due to their exposure of ophiolitic sequences

204 ranging from low-grade to $\mathrm{HP}$ conditions. Peak $P-T$ conditions extend from $160-210^{\circ} \mathrm{C}$ at $0.2-0.3$

$205 \mathrm{GPa}$ in the Bracco unit (Internal Liguride), $270-310^{\circ} \mathrm{C}$ at $0.6 \mathrm{GPa}$ in the Mt. Figogna unit, and

$206300-350^{\circ} \mathrm{C}$ at $0.7 \mathrm{GPa}$ in the Cravasco-Voltaggio unit (Leoni, et al., 1996), to $\sim 550^{\circ} \mathrm{C}$ at $2.0-2.5$

207 GPa in Voltri. Several studies have investigated the fluid mobility and redistribution during the 208 closed system retrogression of the high-pressure Voltri Massif (e.g., Vallis and Scambelluri,

209 1996; Scambelluri et al., 2004, 2007). 
210 Ubaye Valley, France. Exposures at Pic du Pelvat in the Ubaye Valley, France, include

211 ophicarbonates and relatively undeformed pillow basalts, with intact interstitial material. This

212 crustal sequence is overlain by radiolarian chert and carbonate rocks (Tricart and Lemoine, 1986)

213 and all rocks have experienced peak $P-T$ conditions of $325-375^{\circ} \mathrm{C}$ and $1.1-1.4 \mathrm{GPa}$ (Michard et

214 al., 2004). This ophiolite fragment (with aerial exposure of about $1.5 \mathrm{~km}^{2}$ ) was described by

215 Tricart and Lemoine (1986) as an isolated megaboudin (slab) of oceanic crust retaining its

216 original contact with the highly deformed Schistes Lustres metasedimentary section.

217 Monviso, Italy. The two tectonic slices of the Monviso ophiolite preserve eclogite-facies

218 metamorphism at $480-515^{\circ} \mathrm{C}$ at $2.1 \pm 0.3 \mathrm{GPa}$ in the Monviso Unit and 520 to $570^{\circ} \mathrm{C}$ at 2.5 to 2.8

219 GPa in the Lago Superiore Unit (Angiboust et al., 2011, 2012). The metabasalt exposures of the

220 Monviso unit vary greatly with some containing well-preserved carbonate-bearing pillow basalts

221 and pillow breccias, and contain limited exposures of pelitic metasediments in contact with the

222 metabasalts (also see Angiboust et al., 2012). The higher-grade Lago Superiore Unit contains

223 rare exposures of relatively undeformed carbonate-bearing pillow basalts and pillow breccias

224 with local intercalations of pelitic metasedimentary rocks.

225 Cervinia, Italy. The Zermatt-Saas ophiolite contains abundant pristine carbonate-bearing pillow

226 basalts, pillow breccia, hydrothermalized basalts, and talc-schist serpentinites demonstrating

227 little evidence of exhumation related retrogression (Ernst and Dal Piaz, 1978; Angiboust et al.,

228 2009; Angiboust and Agard, 2010). In addition, exposures near Cervinia contain trench-fill

229 pillow basalts, ranging from mm- to m-scale, that are cemented in a carbonate-dominated matrix.

230 While the metamorphic grade of this region $\left(520-560^{\circ} \mathrm{C}\right.$ and $2.2-2.4 \mathrm{GPa}$; Angiboust et al., 2009)

231 overlaps with that of Monviso, Servette, and Clavalité Valley, the dominance of carbonate in

232 contact with well-preserved basalts, limited degree of retrogression, and the abundant garnet- 
233 bearing rocks in the region are of interest in this study. Retention of oxidized and reduced $\mathrm{C}$ in

234 the overlying metasedimentary rocks was investigated by Cook-Kollars et al. (2014).

235 Servette, St. Marcel and Clavalité Valleys, Italy (Zermatt-Saas). At this locality, exposures

236 of pristine carbonate-bearing pillow basalts, pillow breccia, and hydrothermally altered basalts

237 display chemical signatures of extensive seafloor alteration and contain abundant hydrothermal

238 deposits (Martin and Tartarotti, 1989; Martin et al., 2008). These UHP eclogites contain pillow

239 breccia with carbonate mineralogy varying from calcite to magnesite and often associated with

240 chalcopyrite deposits. Peak $P-T$ estimates $\left(530-550^{\circ} \mathrm{C}\right.$ at $\left.\sim 2.4 \mathrm{GPa}\right)$, mapping, descriptions of the

241 metabasalts, and some whole-rock chemical data are presented by Angiboust and Agard (2010).

242 Lago di Cignana, Italy. The UHP metabasalts of Lago di Cignana are the highest-grade rocks

243 investigated in this study (van der Klauw et al., 1997; van der Klauw, 1998; see the petrologic

244 study of the metasedimentary rocks at this locality by Reinecke, 1998). Recent studies have

245 shown evidence of micro-diamond inclusions within garnets from these metabasalts and

246 represent peak $P-T$ paths of $\sim 600^{\circ} \mathrm{C}$ and $\geq 3.2 \mathrm{GPa}$ (Groppo et al., 2009; Frezzotti et al., 2011).

247 Exposures of siliceous and carbonate/pelitic sediments associated with the pillow basalts have

248 previously been studied for evidence of decarbonation (Cook-Kollars et al., 2014). Carbonate-

249 bearing inter-pillow regions and veins are not abundant at this locality (see van der Klauw et al.,

250 1997); however, small amounts of finely disseminated carbonate in whole-rocks afford an

251 opportunity to investigate carbonate retention to depths approaching those beneath arcs.

252 Tianshan, China. Mafic HP rocks of the Tianshan Mountains in western China allow study of

253 devolatilization along the blueschist- and eclogite-facies transition in seafloor-altered basalts

254 metamorphosed at $480-580^{\circ} \mathrm{C}, 1.8-2.1 \mathrm{GPa}$ and in some areas UHP conditions of $500-630^{\circ} \mathrm{C}$ and

255 2.4-3.3 GPa (see Fig. 1B; Klemd et al., 2002; Wei et al., 2003). The HP/UHP unit is interpreted 
to reflect a tectonic mélange or accretionary wedge-like sequence, dominated by forearc sediments. Peak metamorphism occurred at $~ 315$ Ma with the main exhumation processes at 311 Ma (Klemd et al., 2005, 2011). Detailed field and chemical studies (e.g., Gao and Klemd, 2003; John et al., 2008, 2012) have yielded insights into the prograde dehydration of blueschist to carbonate-bearing eclogite veins and multiple textural carbonate setting within the basalts that have seen relatively little exhumation overprinting (Gao and Klemd, 2003; Klemd et al., 2005; Beinlich et al., 2010). van der Straaten et al. (2012) presented a small C and O isotope dataset for HP metabasalts from Tianshan which rehydrated to blueschists during their exhumation along the plate interface and suggested that the low $\delta^{13} \mathrm{C}$ values of some of the carbonates reflect the influence of fluid from a source containing organic/reduced C.

\section{Methods}

\subsection{Carbon and Oxygen Isotope Analyses}

Carbonate from various textural settings (see Table 2) was sampled by micro-drilling using 1 and $2 \mathrm{~mm}$ tungsten carbide bits (data in Supplementary Tables 2,3). The samples were analyzed on a Finnigan MAT 252 using a GasBench II and methods described by Cook-Kollars et al. (2014). Carbonate mineralogy was assessed in part using a Hitachi TM-1000 scanning electron microscope (SEM) and carbonate other than calcite was observed only in metabasaltic samples from Zermatt-Saas (magnesite), Tianshan (ankerite; see van der Straaten et al., 2008, 2012), and Servette (magnesite in one sample suite), and some ophicarbonate samples (dolomite in La Pesca samples; magnesite in some Zermatt-Saas samples). For samples containing only a single carbonate phase, the calcite, dolomite, ankerite, or magnesite was reacted at $72^{\circ} \mathrm{C}$ for 0.5 , 3, 3, or 6 hours (respectively) with $0.2 \mathrm{~mL}$ phosphoric acid to release $\mathrm{CO}_{2}$. Bulk carbonate 
analyses were performed on samples containing multiple carbonate phases, with the reaction time depending on the carbonate phases present. For a small number of samples, separate analyses of calcite and dolomite (by successive acid treatments exploiting the varying reaction rates and at varying temperatures) indicated very little difference in their isotopic compositions. Regular analysis of a house standard and international standard NBS-19 allowed monitoring and correction of the data, resulting in a standard deviation $(1 \sigma)$ of $\sim 0.2 \%$ for both $\delta^{13} \mathrm{C}$ and $\delta^{18} \mathrm{O}$. The $\delta^{13} \mathrm{C}$ and $\delta^{18} \mathrm{O}$ values are reported relative to VPDB and VSMOW, respectively.

A small number of analyses of reduced $\mathrm{C}$ were obtained by first removing carbonate using $1 \mathrm{~N} \mathrm{HCl}$. Samples were then oxidized in sealed $6 \mathrm{~mm}$ (o.d.) quartz tubes and combusted with $\mathrm{Cu}-$ $\mathrm{CuO}_{\mathrm{x}}$ reagent before extraction and analysis by dual-inlet methods (methods in Li and Bebout, 2005). Accuracy was ensured by analyzing the graphite standard USGS-24, for which >50 analyses (over the last ten years) have yielded mean $\delta^{13} \mathrm{C}$ of $-16 \%$ with $1 \sigma$ of $<0.1 \%$. $\delta^{13} \mathrm{C}$ is reported relative to VPDB.

\subsection{Thermodynamic Modeling using Perple_X}

Thermodynamic modeling was computed following the free-energy minimization approach using the software Perple_X (version 6.6.8, April 2013 version; Connolly, 2005) and the thermodynamic database of Holland and Powell (1998; with 2002 revision). Solution models (referred to as Do, Pheng, GlTrTsMr \& GlTrTsPg, Gt, and Chl within the software) were used for carbonates, micas, amphiboles, garnet, and chlorite, respectively (Holland and Powell, 1998). Clinopyroxene stability was computed using the solution model by Gasparik (1989). Mineral end-member calculations for biotite, feldspar, and orthopyroxene were also considered but were not these phases were not stabilized at the selected $P-T$ range and for the rock compositions investigated (compositions in Supplementary Table 4). The volatiles $\mathrm{H}_{2} \mathrm{O}$ and $\mathrm{CO}_{2}$ were 
302 considered as thermodynamic components (not saturated phases) for the closed-system

303 pseudosections and as saturated phases for the $\mathrm{T}-\mathrm{X}_{\mathrm{CO}_{2}}$ calculations. $\mathrm{H}_{2} \mathrm{O}$ - and $\mathrm{CO}_{2}$-bearing fluid

304 behavior was modeled using the CORK equation of state by Holland and Powell (1991, 1998).

306 4. Results

\subsection{Field Relations and Petrography}

\subsubsection{Metabasaltic Rocks}

309 Generalized field textures and textural occurrences of carbonate at the sampling localities are

310 presented in Table 2, with representative examples shown in the field photographs in Fig. 2.

311 Most of the sampled exposures contain metabasaltic rocks showing little evidence for

312 deformation at the macroscopic scale and containing clear pillow/interpillow structures and veins

313 of varying textures, along with breccia, making it possible to sample carbonate from a variety of

314 textural settings at single localities. Carbonate, mostly calcite, also occurs as a finely

315 disseminated whole-rock phase and in relatively non-abundant micro- and macro-scopic scale

316 veins and segregations. At the sites containing basaltic or gabbroic breccias, carbonate occurs as

317 the dominant breccia filling (see Fig. 2D). Contacts of carbonate breccia fillings with

318 metabasaltic clasts show no mineralogical evidence of metasomatic exchange - such

319 metasomatism, had it occurred, might have driven some decarbonation (Thompson, 1975;

320 Joesten, 1977; Ague and Rye, 1999; Bebout, 2013). Conspicuously absent in the W. Alps

321 exposures are cm- to m-scale, through-going (i.e., at scales beyond those of individual small

322 outcrops) veins indicating larger-scale fluid mobility (e.g., of the type described for Tianshan

323 localities; see van der Straaten et al., 2008, 2012; Beinlich et al., 2010; John et al., 2012). 
It is difficult petrographically to deduce mineralogical records of whole-rock decarbonation in the metabasalts, as the mineral assemblages are very similar to those expected as the result of HP/UHP metamorphism without any involvement of carbonate in prograde reactions. Calciumrich phases that could in part reflect decarbonation of calcite or dolomite include garnet, omphacitic pyroxene, lawsonite, clinozoisite, as described in the previous petrologic studies of these localities cited in Section 2 (discussion of this complication in Sections 4.4 and 5.1.1).

The carbonate sampled for this study, and analyzed for its $\mathrm{C}$ and $\mathrm{O}$ isotope compositions, is

331 from a variety of textural settings (see Table 2, Supplementary Table 2). As noted in Section

332 3.1, for the metabasalts, carbonate other than calcite occurred only in samples from Zermatt-Saas

333 (magnesite), Tianshan (ankerite; see van der Straaten et al., 2008, 2012), and Servette (magnesite

334 in one sample suite). Many of the metabasaltic rocks contain 1-5 wt. \% finely disseminated

335 carbonate (as obtained from isotope extractions), in some cases not visible petrographically, but

336 the dominant reservoirs for carbonate are in small-scale $(<50 \mu \mathrm{m}$ wide $)$ veins of varying textures, 337 breccia matrices, and interpillow regions. In some samples, $\mu \mathrm{m}$ to $\mathrm{mm}$ scale pods and veinlets 338 are discontinuous beyond the scale of individual thin sections (several tens of mms), whereas 339 others are through-going beyond this scale (up to $\mathrm{cm}$ and $\mathrm{m}$ scales) in rocks lacking penetrative 340 deformation fabric. Some breccias contain $>25 \%$ carbonate by volume (see the example in Fig. 341 2D), again, showing no obvious mineralogical evidence of reaction between the carbonate and 342 the silicate mineral assemblages in the metabasaltic or metagabboic clasts.

\subsubsection{Ultramafic Rocks (Ophicarbonates)}

344 The ophicarbonate exposures sampled in this study, across all grades, are mostly breccias 345 with variably metasomatized serpentinite clasts ( $\mathrm{cm}$ to $\mathrm{m}$ scales) and extremely abundant 346 carbonate as breccia filling and veins (together, up to 30 vol. \% of some exposures) showing a 
347 wide range of textures indicating their stages of evolution. At a few of the localities, the

348 ophicarbonates show the development of later-stage, more penetrative cleavage, in some cases

349 with intensely foliated rocks in which breccia textures are largely destroyed and nearby domains

350 of non-foliated breccia, separated by deformation "fronts." The contacts between these highly

351 deformed and undeformed ophicarbonates can be quite sharp, with strong gradients in extent of

352 foliation over $\mathrm{cm}$ scales. The more foliated rocks tend to contain few veins cross-cutting their

353 foliation. Although the majority of the ophicarbonates contain calcite as the dominant carbonate

354 phase, samples from La Pesca contain abundant dolomite and some Zermatt-Saas samples

355 contain magnesite.

4.2 Carbon and Oxygen Isotope Compositions of Carbonate (and Reduced Carbon) in

Metabasaltic Rocks individual sampling localities in Fig. 4. The carbonate occurrences at individual localities tend to show variation related to the textural setting of the carbonate, but there is significant overlap

362 among the datasets for the various localities. Also shown in Fig. 3 are ranges in $\mathrm{C}$ and $\mathrm{O}$ isotope compositions of finely disseminated (whole-rock) calcite in various altered basalts on the modern

364 Atlantic seafloor (from Furnes et al., 2001) and data for calcite veins in seafloor-altered basalts

365 (from Alt and Teagle, 2003; Coggon et al., 2010; R. Coggon, pers. comm., 2014). The data for 366 the veins and finely disseminated carbonate in the metamorphic suites investigated here tend to 367 show $\delta^{13} \mathrm{C}$ similar to, but $\delta^{18} \mathrm{O}$ lower than, values for carbonate from similar textural settings in 368 basalts on the modern seafloor. However, the carbonate $\delta^{18} \mathrm{O}$ values mostly fall within the range 369 of whole-rock $\delta^{18} \mathrm{O}$ values for altered oceanic crust $(+5$ to $+20 \%$, mostly +5 to $+10 \%$; from Alt 
and Teagle, 2003; Alt, 2004). The carbonate $\delta^{18} \mathrm{O}$ values for the Zermatt-Saas samples ( +9 to +20\%; green-filled symbols in Fig. 3) show a wide range encompassing the smaller ranges for the other units, among which there is more limited overlap.

Several suites demonstrate differences in values for whole-rock, including finely disseminated, carbonate and values for carbonate sampled from various other textural settings by micro-drilling (see Fig. 4). Carbonate in the lowest-grade (prehnite-pumpellyite facies) metabasalts, from the Bracco unit, have $\delta^{13} \mathrm{C}$ of -4.5 to $+2.0 \%$ and $\delta^{18} \mathrm{O}$ values of +16 to $+21.3 \%$ (see the previous work by Barrett and Friedrichsen, 1989). Except for several wholerock samples (red-filled squares), the data for the Bracco Unit range in $\delta^{13} \mathrm{C}$ values from -1.5 to $+2.0 \%$ and show fairly uniform $\delta^{18} \mathrm{O}$ of +16 to $+17.3 \%$ (see Fig. 4A). Increasing in grade, discontinuous veins and pods in Mt. Figogna Unit metabasalts have $\delta^{13} \mathrm{C}$ values of -0.2 to $+0.8 \%$ and $\delta^{18} \mathrm{O}$ values of +12.4 to $+13.2 \%$, with one whole-rock sample having higher $\delta^{18} \mathrm{O}$ near +17\% (Fig. 4A). Approaching the blueschist facies, whole-rock analyses from the CravascoVoltaggio unit display $\delta^{13} \mathrm{C}$ values of -2.6 to $+0.8 \%$ and $\delta^{18} \mathrm{O}$ values of +18.0 to $+25.8 \%$ (see Fig. 3). Blueschist-facies metabasalts from Ubaye Valley, France, display large variation in whole-rock carbonate $\delta^{13} \mathrm{C}$ of -12 to $+0.3 \%$, correlated with $\delta^{18} \mathrm{O}$ varying from +15.1 to $+24.9 \%$ o (see this trend in Fig. 4C). However, carbonate in discontinuous and through-going veins has $\delta^{13} \mathrm{C}$ of -5.1 to $+2 \%$ and shows tighter clustering in $\delta^{18} \mathrm{O}$ of +14.0 to $+16.9 \%$. Carbonate from various textural settings in rocks from the Lago Superiore unit at Monviso contain $\delta^{13} \mathrm{C}$ values of -0.8 to $+2.5 \%$ and $\delta^{18} \mathrm{O}$ values of +8.5 to $+15.9 \%$ (Fig. 4B). Through-going veins (green-filled diamonds) are relatively uniform in $\delta^{18} \mathrm{O}(+11.5$ to $+12.5 \%)$ and define a curved array between endmember $\delta^{13} \mathrm{C}$ values of $+2.5 \%$ and $-0.8 \%$. The Monviso unit at Monviso contains carbonate with $\delta^{13} \mathrm{C}$ of -0.4 to $+1.2 \%$ however, with $\delta^{18} \mathrm{O}$ values of +12.4 to $+15.0 \%$ higher than those of 
most Lago Superiore carbonate. Metabasalts from the Zermatt-Saas ophiolite show clustering of

$394 \delta^{13} \mathrm{C}$ values between -1.6 and $+1.9 \%$ while having a broad range of $\delta^{18} \mathrm{O}$ values of +9.1 to

$395+19.2 \%$, showing little relationship with varying textures (Fig. 4D). The highest-grade

396 metabasalts, at Lago di Cignana (UHP), display a wide range of whole-rock $\delta^{13} \mathrm{C}$ values

397 spanning from -6.1 to $+0.7 \%$ and $\delta^{18} \mathrm{O}$ values of +11.5 to $+21.9 \%$, producing a linear array (red-

398 filled squares in Fig. 4D).

399 Eclogites from the Tianshan show a wide range of carbonate $\delta^{13} \mathrm{C}$, from -14.1 to $+2.8 \%$,

400 whereas $\delta^{18} \mathrm{O}$ shows a smaller range of +9.9 to $+15.8 \%$, and these data (for whole-rocks and

401 discontinuous pods) form a strong trend (see the black arrow on the left in Fig. 3). These samples

402 represent three traverses, one the envelope of a large vein (fluid conduit; see Zack and John,

403 2007) and the others of rocks partially rehydrated during fluid-rock interaction along the plate

404 interface (see van der Straaten et al., 2008, 2012). For comparison, the data for metabasalts in the

405 Catalina Schist (from Bebout, 1995) similarly show a range of $\delta^{13} \mathrm{C}$ to values considerably lower

406 than those expected for seafloor alteration, at relatively uniform $\delta^{18} \mathrm{O}$. Among the sample suites

407 for the localities in Italy and France, only Ubaye and Lago di Cignana show well-defined trends

408 of covarying $\delta^{18} \mathrm{O}$ and $\delta^{13} \mathrm{C}$, in both cases toward higher $\delta^{18} \mathrm{O}$ and lower $\delta^{13} \mathrm{C}$ values approaching

$409-15 \%$ (Figs. 3, 4C,D).

410 Several higher-grade metabasaltic samples were analyzed for their whole-rock C

411 concentrations after pre-treatment with $\mathrm{HCl}$ (to dissolve carbonate), using the sealed-tube

412 methods described in Section 3.1. Analyses of two Zermatt-Saas metabasaltic rocks yielded

413 concentrations of 0.12 and 0.04 wt. $\% \mathrm{C}$ with $\delta^{13} \mathrm{C}$ of -22.4 and $-26.7 \%$, respectively. One

414 Monviso UHP metabasaltic rock yielded a C concentration of 0.07 wt. \% (700 ppm) with $\delta^{13} \mathrm{C}$ of $415-5.1 \%$. 


\subsection{Carbon and Oxygen Isotope Compositions of Carbonate in Ophicarbonates}

Carbon and $\mathrm{O}$ isotope compositions of the carbonate in the ophicarbonates are shown in Fig. 5 (see data in Supplementary Table 3), compared with the compositions of ophicarbonates from various settings, including the seafloor (the latter from Clerc et al., 2014). Most of the samples have $\delta^{13} \mathrm{C}$ in the range of +0.3 to $+3.0 \%$, but with the various suites show varying ranges and relationships in their $\delta^{18} \mathrm{O}$. The highest-grade units (Voltri Massif, Zermatt-Saas) show the most tightly clustered and lowest $\delta^{18} \mathrm{O}$ values $(+9.9$ to $+12.6 \%$ ).

The prehnite-pumpellyite facies Bracco unit ophicarbonates show a range of $\delta^{13} \mathrm{C}$ values of +0.6 to $+2.8 \%$ and $\delta^{18} \mathrm{O}$ values of +14.4 to $+22.2 \%$, showing no obvious trends. Slightly increasing in grade, several samples of ophicarbonates from the Mt. Figogna unit tightly cluster in $\delta^{13} \mathrm{C}\left(+0.7\right.$ to $+1.2 \%$ ) and $\delta^{18} \mathrm{O}(+14.0$ to $+14.9 \%)$. Comparable in grade with Mt. Figogna, ophicarbonates from nearby Montaretto have $\delta^{13} \mathrm{C}$ values of +1.0 to $+2.6 \%$, however, show a broad range of $\delta^{18} \mathrm{O}$ values from +15.1 to $+24.6 \%$ (Supplementary Table 3; also see Schwarzenbach et al., 2013). Blueschist-facies ophicarbonates from Ubaye Valley, France, display the largest range in $\delta^{13} \mathrm{C}$ values of the suites we investigated, spanning from -3.0 to $+1.8 \%$ and $\delta^{18} \mathrm{O}$ values of +16.0 to $+25.4 \%$. Interestingly, the metabasaltic carbonate for Ubaye also shows this range to low $\delta^{13} \mathrm{C}$ (see Figs. 3, 4C). Eclogite-facies ophicarbonates from the Zermatt-Saas ophiolite span a range in $\delta^{13} \mathrm{C}$ values from -0.4 to $+3.0 \%$ with a narrow range of $\delta^{18} \mathrm{O}$ values $(+9.9$ to $+12.6 \%$ ). Data for ophicarbonates from the Voltri Massif fall within the range of data for the Zermatt-Saas ophiolite, the other higher-grade (eclogite-facies) locality, with $\delta^{13} \mathrm{C}$ values of +0.9 to $+1.8 \%$ and $\delta^{18} \mathrm{O}$ values of +10.1 to $+11.3 \%$.

In general, the arrays of $\mathrm{O}$ and $\mathrm{C}$ isotope data for ophicarbonates and metabasalts from the same locality tend to overlap but show considerable differences in distribution (compare Figs. 3 
and 4). For example, for the Bracco Unit, data for metabasalts show relatively uniform $\delta^{18} \mathrm{O}$ of +16 to $+17.5 \%$ ) and $\delta^{13} \mathrm{C}$ ranging from -1.5 to $2.0 \%$. The ophicarbonates from the same locality have $\delta^{13} \mathrm{C}$ of +0.5 to $+3.0 \%$ and a show a wider range in $\delta^{18} \mathrm{O}$ of $\sim+13.8$ to $+21.5 \%$. As another comparison, the Zermatt-Sass metabasalt carbonate ranges widely in $\delta^{18} \mathrm{O}$, from +9 to $+20 \%$, with $\delta^{13} \mathrm{C}$ of -2.5 to $+2 \%$. The ophicarbonate from the Zermatt-Saas shows a far more narrow range in $\delta^{18} \mathrm{O}$ but $\delta^{13} \mathrm{C}$ of -0.5 to $+3.0 \%$ that largely overlaps the $\delta^{13} \mathrm{C}$ range for the metabasalts. 4.4 Thermodynamic Modeling of the Devolatilization of the Metabasalts and Ophicarbonates

Pseudosections for four MORB compositions representing closed systems, generated using Perple_X, are shown in Fig. 6 (the system modeled was NCKFMASH $+\mathrm{CO}_{2}$; compositions are provided in Supplementary Table 4). The bulk compositions modeled in these calculations were selected to represent a wide range of alteration states and carbonate concentrations of seafloor-altered basaltic rocks (see Alt, 2004), with the composition for basalts at ODP Site 417/418 representing the most altered rocks. On these figures, dashed white lines represent an array of cool to warm modern-day subduction zone $P$ - $T$ paths from Syracuse et al. (2010) and van Keken et al. (2011; also P. van Keken, personal communication, 2013). The most significant changes in mineralogy, representing significant devolatilization, are shown with large dashed lines and arrows. For greater simplicity, minor oxide occurrences, as well as carbonate mineralogy, are excluded from the field labels. On these figures, the spectrum of colors represents $\mathrm{CO}_{2}$ concentration and, on each, these concentrations show little change along lowerP, forearc parts of the $P-T$ paths and significant decrease beginning at about $600^{\circ} \mathrm{C}$ and at pressures of 2.0 to $2.75 \mathrm{GPa}$ corresponding to $60-90 \mathrm{~km}$ depths (depending on the $P$ - $T$ path).

Figure 7 shows the calculated modal abundances of major silicate minerals and carbonates from the average composition of ODP core 417/418 (Staudigel et al., 1996) along the subduction 
zone $P$-T paths for the four modern margins shown in Fig. 6C (paths from Syracuse et al., 2010; van Keken et al., 2011; P. van Keken, personal communication, 2013). To simplify the figure, minor mineral occurrences are omitted and carbonate mineralogy is indicated as an aggregate. Along each $P$-T path, garnet crystallization increases mostly at the expense of lawsonite. A decrease or loss of carbonates is coupled with the increase in clinopyroxene and to a lesser degree garnet. Glaucophane breakdown produces no changes in the modal abundances of major minerals or carbonates. Based on these variations in modal abundances, generalized reactions along these paths are likely to be of the following generalized types:

\section{Reaction occurring prior to breakdown of carbonate:}

$$
\text { glaucophane }+ \text { garnet }=\text { clinopyroxene }+\mathrm{H}_{2} \mathrm{O}(\text { Figs. 7A,B,C })
$$

\section{Reactions involving breakdown of carbonate:}

$$
\begin{aligned}
& \text { lawsonite }+ \text { clinopyroxene }+ \text { carbonate }=\text { garnet }+\mathrm{H}_{2} \mathrm{O}+\mathrm{CO}_{2}(\text { Figs. 7A,B }) \\
& \text { garnet }+ \text { carbonate }=\text { clinopyroxene }+\mathrm{CO}_{2}(\text { see Figs. 7C,D })
\end{aligned}
$$

Note that, for all $P-T$ paths, lawsonite is produced prior to significant carbonate breakdown, thus presumably not via a decarbonation reaction. Glaucophane is not stabilized along the warmest $P-T$ path, that for Cascadia (see Fig. 7D). Along all paths, beyond $\sim 2.5 \mathrm{GPa}$, a bulk composition such as this (ODP Site 417/418) would stabilize a classic eclogite assemblage of clinoproxene+garnet largely devoid of volatiles, other than $\mathrm{CO}_{2}$ in any residual carbonate, unless phases such as phengite are stabilized by small amounts of $\mathrm{K}_{2} \mathrm{O}$ incorporated during seafloor alteration (see Bebout, 2007a). The superposition of these calculations and the various $P-T$ paths show that, in the unlikely case where the released volatiles are still present (i.e., have not physically left the rock/system), some re-incorporation is possible at $>3.0 \mathrm{GPa}$. 
Figure 8A shows isopleths of $\mathrm{H}_{2} \mathrm{O}$ and $\mathrm{CO}_{2}$ for the closed-system model of the more altered rock composition from ODP core 417/418 (see Figs. 6C,7), the peak $P$ - $T$ estimates for the metabasaltic sites sampled in this study (shaded rectangular regions; see Fig. 1B), and the 487 modern-day subduction $P$ - $T$ paths from Fig. 6 (and also several $P$ - $T$ paths from Gerya et al., 488 2002; see the figure caption). Significant dehydration $(\sim 65 \%)$ is evident for the higher-grade 489 suites studied here but little or no decarbonation is indicated for prograde metamorphism to these 490 peak conditions. Along the $P-T$ paths from Syracuse et al. (2010) for the various modern margins 491 (thick grey lines), excluding the path for the very warm Cascadia margin, decarbonation reaction 492 begins to occur at temperatures of $\sim 600^{\circ} \mathrm{C}$ and the maximum extents of decarbonation experienced by rocks along these paths are $7 \%$ for Tonga, $43 \%$ for Northern Vanuatu, and 100\% 494 for Nankai (the latter also a relatively warm margin). Figure 8B shows profiles of $\mathrm{H}_{2} \mathrm{O}$ and $\mathrm{CO}_{2}$ wt. \%, plotted vs. pressure (and corresponding temperature), for a "cool” margin (Tonga), a 496 margin "intermediate" in its $P$ - $T$ path (Northern Vanuatu), and a "warm" margin (Cascadia). On 497 this figure, it is again clear that varying degrees of dehydration occur along earlier parts of these 498 paths and to the peak-metamorphic $P-T$ conditions for the units we sampled. As shown in Fig. 7, 499 this $\mathrm{H}_{2} \mathrm{O}$ loss is largely due to the breakdown of glaucophane and/or lawsonite giving way to 500 clinopyroxene. More significant losses of $\mathrm{CO}_{2}$ along the paths for Northern Vanuatu, Nankai, 501 and Cascadia (see Figs. 7B,C,D) correspond to increase in the abundance of clinopyroxene.

502 The effect of infiltration by extremely $\mathrm{H}_{2} \mathrm{O}$ rich fluids on mineral reaction for the 503 composition representative of ODP Site 417/418 (from Staudigel et al., 1996) is demonstrated 504 for two pressures (1.5 and $2.5 \mathrm{GPa})$ in the $\mathrm{T}-\mathrm{X}_{\mathrm{CO}_{2}}$ diagrams in Fig. 9. On these figures, 505 carbonate is again simplified for clarity. Figures $9 \mathrm{~A}$ and $\mathbf{B}$ present the same ranges in $\mathrm{XCO}_{2}$ 506 values at pressures of 1.5 and $2.5 \mathrm{GPa}$ (respectively) and panels $1-4$ below show the modal 
abundances calculated for along pathways toward lower $\mathrm{XCO}_{2}$ at two temperatures (450 and $550^{\circ} \mathrm{C}$ ) at each pressure (see the arrows pointing from higher to lower $\mathrm{X}_{\mathrm{CO}_{2}}$ ). As for the closedsystem calculations, garnet crystallization occurs largely at the expense of lawsonite. The

510 dramatic losses of carbonate are accompanied by large increase in clinopyroxene abundance and, 511 at the higher temperature, also some increase in the abundance of garnet. In the calculation for

$512 \quad 1.5 \mathrm{GPa}$ and $550^{\circ} \mathrm{C}$, the decrease in the abundance of carbonate is more gradual than in the three

513 other calculations and is accompanied by decrease in lawsonite abundance and increased

514 abundance of garnet and, to a lesser extent, glaucophane.

515 Figure 10 shows a calculation of $\mathrm{H}_{2} \mathrm{O}$ and $\mathrm{CO}_{2}$ wt. \% as a function of extents of 516 devolatilization for an ophicarbonate composition and the $P-T$ paths also shown in Fig. 8A. The

517 peak $P-T$ estimates for the ophicarbonates investigated in this study are shown as dark-shaded 518 boxes and it is evident from this calculation that, in a closed system, little or no decarbonation 519 would be expected. In the modern margins represented by the four $P-T$ paths from Syracuse et al. 520 (2010), modest amounts of decarbonation would be expected over the 2.0 to $3.0 \mathrm{GPa}$ interval.

\section{Discussion of Results}

523 Our integrated field, petrologic, theoretical, and geochemical approach allows a broad 524 consideration of the extent to which $\mathrm{C}$ is retained in metabasaltic and metaultramafic rocks 525 subducted to depths approaching those beneath arc volcanic fronts. Here, it is again worth noting 526 that our work was conducted on large, relatively coherent/intact exposures of metabasaltic rocks 527 and ophicarbonates, for the most part without obvious shear zones, and that with the exception of 528 the Tianshan exposures we investigated, these exposures tended not to contain larger, more 529 through-going vein sets indicative of open-system behavior. 


\subsection{Metabasaltic Rocks}

531

\subsubsection{Field Relations and Petrography of the Metabasaltic Rocks}

Preservation of abundant carbonates in the relatively undeformed metabasalts, particularly in pillow/interpillow structures and pillow breccias, demonstrates the widespread retention of $\mathrm{CO}_{2}$ (Table 2) in Italian/French Alps HP/UHP metabasalts subducted to depths of up to $90 \mathrm{~km}$ (Fig.

2). This evidence for the retention of carbonate is consistent with observations made in previous studies (e.g., Barnicoat and Cartwright, 1995; Rubatto et al., 1998; Cartwright and Barnicoat, 1999, 2003; Miller and Cartwright, 2000) and argues against the extensive decarbonation calculated for open-system models by Gorman et al. (2006). Unlike the larger, more throughgoing veins in the Tianshan (investigated by Beinlich et al., 2010; John et al., 2012; van der Straaten et al., 2012), which do show evidence for carbonate mobility, and the veins studied by Ague and Nicolescu (2014), the veins in the Italian exposures we investigated do not show obvious field or petrographic evidence of leaching or addition of carbonate in well-developed envelopes. However, it is possible that small amounts of carbonate were dissolved by infiltrating fluids, particularly from rocks showing evidence of control of their isotopic compositions from an external reservoir (e.g., metabasalts showing tight ranges in $\delta^{18} \mathrm{O}$ or correlated shift in $\delta^{18} \mathrm{O}$ and $\delta^{13} \mathrm{C}$; see Figs. 3,4; see discussion of this possible open-system behavior in Section 5.1.2). Small amounts of carbonate dissolution, distributed over very large rock volumes, could constitute significant mobilization of $\mathrm{C}$ from or within slabs.

Petrographic/mineralogical identification of decarbonation in the HP/UHP metabasalts is made difficult by the fact that the mineral phases produced by such reactions are stabilized without the need for involvement of carbonates (see the calculations in Fig. 6 for basalts containing a wide range of initial $\mathrm{CO}_{2}$ concentrations). However, for a small number of samples, 
553 from Ubaye and Tianshan, possible evidence of decarbonation occurs as reaction rims at contacts

554 between mafic breccia clasts and carbonate cement. Within pillow matrices, across the wide-

555 range of $P-T$ represented by our localities, carbonate is predominantly finely disseminated and

556 displays little evidence of reaction with surrounding silicates to produce calc-silicate phases and

557 release $\mathrm{CO}_{2}$. In a small number of metabasalts, discontinuous carbonate-bearing veins show

558 reaction rims with amphibole, epidote, and omphacite, pointing to local-scale metasomatic

559 reaction possibly involving $\mathrm{CO}_{2}$. The surprisingly small number of through-going carbonate-

560 bearing veins in these relatively undeformed metabasaltic exposures (most of them preserving

561 pillow textures; see Table 2; Figs. 2A-C) is consistent with limited degrees of large-scale

562 fracture-related fluid-flow (i.e., fluid mobility at scales greater than the individual outcrops).

$563 \quad 5.1 .2$ Isotopic Evidence for Closed to Limited Open-System Behavior during Subduction-Zone

564 Metamorphism of the Metabasaltic Rocks

565 The $\mathrm{C}$ and $\mathrm{O}$ isotope data for the metabasalts (see Figs. $\mathbf{3 , 4}$ ) allow some assessments of 566 extents of open- and closed-system behavior and, where open-system behavior is indicated, the

567 compositions and possible sources of the externally-derived fluids. In this discussion of the

568 isotopic data, we do not consider in detail the consequences of having minor amounts of

569 dolomite, ankerite, or siderite in some samples, in addition to the far more abundant calcite.

570 Fractionation of $\mathrm{C}($ and $\mathrm{O})$ isotopes among these phases is minor, near $0.5 \%$ ( $\left(10^{3} \ln \alpha\right)$, over the

571 temperature range of $400-600^{\circ} \mathrm{C}$ (see Sheppard and Schwarz, 1970).

572 The majority of the suites retain carbonate $\delta^{13} \mathrm{C}$ overlapping with that of carbonates

573 produced during seafloor alteration; however, the $\delta^{18} \mathrm{O}$ values are significantly lower than those

574 for the seafloor carbonates (see Figs. 3, 4). Although shifts to lower $\delta^{18} \mathrm{O}$ could be accomplished 575 through open-system behavior, involving infiltration by fluids from external sources, we suggest 
that (particularly for the finely disseminated carbonate, micro-veins, and segregations) these shifts could be the result of more closed-system exchange between the carbonate and the modally dominant silicate mineral assemblage. Calculation of equilibration of calcite $\delta^{18} \mathrm{O}$ with clinopyroxene and garnet, at $500-600^{\circ} \mathrm{C}$, in a fictive eclogite with whole-rock $\delta^{18} \mathrm{O}$ of $+10 \%$ (using fractionation factors from Zheng, 1993) yields values near $+13 \%$ within the range of observed values for the finely disseminated carbonate (see Fig. 3). A number of other authors have concluded that HP/UHP metabasaltic rocks can behave largely as closed systems during metamorphism, based in part on O isotope compositions (see Barnicoat and Cartwright, 1995; Cartwright and Barnicoat, 1999, 2003; Miller et al., 2001; Nadeau et al., 1993; Philippot, 1993). Decarbonation involving finely disseminated calcite in the metabasalts would be expected to produce lowering of $\delta^{13} \mathrm{C}$, with or without change in $\delta^{18} \mathrm{O}$, the $\mathrm{O}$ shifts depending on the extents to which the decarbonation is driven by infiltration by externally-derived $\mathrm{H}_{2} \mathrm{O}$-rich fluids (and the $\delta^{18} \mathrm{O}$ of these fluids). For the closed-system case, with no infiltration, decreases in $\delta^{18} \mathrm{O}$ due to decarbonation are strongly limited by the relatively small fractions of $\mathrm{O}$ removed in the $\mathrm{CO}_{2}$ (i.e., the large fraction of $\mathrm{O}$ left in the residue in silicate phases and any residual carbonate). For extensive decarbonation of finely disseminated carbonate, where the fraction of $\mathrm{C}$ remaining can approach or reach 0 , shifts of up to $10 \%$ or greater are possible by a Rayleigh distillation process (see Valley, 1986). One representative path in O-C isotope composition that residual carbonate might take for a Rayleigh process is shown in Fig. 3. It would be difficult to identify the small shifts in $\delta^{18} \mathrm{O}$ potentially associated with closed-system decarbonation, given the very large range of possible starting $\delta^{18} \mathrm{O}$ values related to seafloor alteration (see Alt et al., 1996; Alt and Teagle, 2003; Furnes et al., 2001) and the superimposed exchange with silicate phases. However, the lack of shift of $\delta^{13} \mathrm{C}$ to beyond the range expected for seafloor-altered basalts, observed for most 
of the metabasaltic suites, is consistent with little or no decarbonation. For the case of an infiltrating extremely $\mathrm{C}$-poor, $\mathrm{H}_{2} \mathrm{O}$-rich fluid driving decarbonation reaction, any $\delta^{13} \mathrm{C}$ shift would be purely the result of decarbonation, and the exact direction and magnitude of $\delta^{18} \mathrm{O}$ shift would depend on the $\delta^{18} \mathrm{O}$ of the fluid and the temperature at which the residual carbonate equilibrated with that fluid (see the double-headed arrow near the top of Fig. 3 labeled, "Exchange with $\mathrm{H}_{2} \mathrm{O}$-Rich Fluid").

For a few of the suites, isotopic compositions are indicative of some open-system behavior and, in some cases, consistent with equilibration with fluids derived in nearby metasedimentary rocks (see the data for these metasedimentary sections in Cook-Kollars et al., 2014). The relatively uniform $\delta^{18} \mathrm{O}$ for veins in the low-grade Bracco Unit (Fig. 4A) indicates the possibility of some control of isotopic compositions by exchange with an externally-derived fluid with relatively uniform $\delta^{18} \mathrm{O}$ but that did not result in $\delta^{13} \mathrm{C}$ differing from that typical for seafloor altered basalts (compare with the ranges of $\delta^{13} \mathrm{C}$ in Fig. 3). Some whole-rock carbonate in these metabasalts (red-filled squares) is considerably higher in $\delta^{18} \mathrm{O}$ and shows a wide range of $\delta^{13} \mathrm{C}$ values, perhaps reflecting differential control by infiltrating fluids and greater preservation of isotopic compositions inherited from the seafloor or influenced by some decarbonation (the latter producing shift to lower $\delta^{13} \mathrm{C}$ values). Whole-rock, finely disseminated carbonate in blueschist metabasalts from the Ubaye Valley shows shifts towards more organic-rich $\delta^{13} \mathrm{C}$ signatures (Fig. 4C), perhaps in part reflecting decarbonation or isotopic exchange with minor reduced $\mathrm{C}$ in these samples, and correlated shift to higher $\delta^{18} \mathrm{O}$. These shifts could reflect exchange with externallyderived, C-bearing, $\mathrm{H}_{2} \mathrm{O}$-rich fluids, with or without some shift associated with decarbonation. Similar relationships are exhibited by whole-rock data for very low-carbonate UHP metabasalts from Lago di Cignana. Data for more through-going veins in the Lago Superiore Unit at 
622 Monviso (green-filled diamonds in Fig. 4B) show a modest range of $\delta^{13} \mathrm{C}$ but a very narrow

623 range of $\delta^{18} \mathrm{O}$, the latter perhaps reflecting control of $\mathrm{O}$ isotope composition by fluids with

624 uniform $\delta^{18} \mathrm{O}$ from an external source. The range in $\delta^{13} \mathrm{C}$ of these Lago Superiore veins (note the

625 varying $\mathrm{y}$-axis ranges in $\delta^{13} \mathrm{C}$ in the plots in Fig. 4) contrasts with the far larger ranges in $\delta^{13} \mathrm{C}$,

626 also at fairly uniform $\delta^{18} \mathrm{O}$, seen for the Tianshan and Catalina Schist metabasalts (see Fig. 3).

627 The data for these latter two suites could reflect exchange with fluids with uniform $\delta^{18} \mathrm{O}$ but that 628 previously equilibrated differentially with organic-rich sediments during entrainment into a shear 629 zone (for some samples, perhaps with some superimposed isotopic effects of decarbonation; for 630 discussion of the Catalina Schist data, see Bebout, 1995).

631 For some of the Alps suites, the $\delta^{18} \mathrm{O}$ of calcite showing relatively narrow ranges, without 632 appreciable shift in $\delta^{13} \mathrm{C}$ from the range for altered seafloor basalts, differs significantly from the 633 calcite $\delta^{18} \mathrm{O}$ values in nearby calc-schists of similar grade that could perhaps be viewed as 634 potential fluid sources. The best examples of this relationship are the subset of MV-LS samples 635 showing more through-going textures (green-filled diamonds in Fig. $4 \mathbf{B} ; \delta^{18} \mathrm{O}$ near $+12 \%$ ) and 636 data for various vein types at the Bracco Unit localities $\left(\delta^{18} \mathrm{O}\right.$ near $\left.+16.5 \%\right)$. Neither of these 637 isotopic compositions is consistent with equilibration with carbonate from the calc-schists (via 638 fluids), which at these grades has $\delta^{18} \mathrm{O}$ near $+18 \%$ (Monviso) and $+25 \%$ (estimated for Bracco; 639 see Cook-Kollars et al., 2014). The lower- $\delta^{18} \mathrm{O}$ fluids producing these arrays could have been 640 largely from another source such as dehydrating mafic or ultramafic rocks at greater depths in 641 the subduction zone, perhaps with some in-mixing of fluids evolved in the calc-schist/metapelite 642 section. The trends toward higher $\delta^{18} \mathrm{O}$ and lower $\delta^{13} \mathrm{C}$ for some of the samples from the Ubaye 643 Unit and the Zermatt-Saas localities (the gray-shaded diagonal arrow in Fig. 3) are consistent 
644 with a shift toward equilibrium with fluids equilibrated with interlayered calc-schists and metapelites of the Schistes Lustres exposed nearby.

\subsubsection{Theoretical Evidence for Decarbonation History of the Deeply Subducted Metabasalts}

The thermodynamic calculations for closed systems presented in this paper, and by Kerrick and Connolly (2001b), indicate that very little decarbonation would occur at forearc depths along the $P$-T metamorphic gradient investigated in this study (and by Cook-Kollars et al., 2014), and along forearc $P-T$ paths experienced in most modern subduction margins. For the compositions considered in this study, and by Gorman et al. (2006), significant decarbonation occurs only at very low $\mathrm{XCO}_{2}$, a condition that seemingly would require infiltration of the rocks by $\mathrm{H}_{2} \mathrm{O}$-rich fluids (see Fig. 9). For depths greater than those investigated in these field localities (i.e., >90 km), even the closed-system calculations indicate significant decarbonation, depending on the $P$ $T$ path the rocks experience (Figs. 6, 8). Use of the more recently published $P-T$ paths (Syracuse et al., 2010; van Keken et al., 2011) produces far larger $\mathrm{CO}_{2}$ loss over the depth interval of 80$120 \mathrm{~km}$ than was suggested by Kerrick (2001a,b), who considered earlier models that did not take into account the heating of slabs by the convecting mantle wedge.

These calculations for the metabasaltic rocks would permit infiltration of the metabasalts by fluids that were $\mathrm{H}_{2} \mathrm{O}$-rich (i.e., had high $\mathrm{O} / \mathrm{C}$ ) but had $\mathrm{X}_{\mathrm{CO}_{2}}$ higher than that required to drive decarbonation reaction. This scenario would conceivably produce shifts in carbonate $\delta^{18} \mathrm{O}$ without as obvious shifts in $\delta^{13} \mathrm{C}$ (see the arrow in Fig. 3 labeled "Exchange with $\mathrm{H}_{2} \mathrm{O}-\mathrm{Rich}$ Fluid"), depending on the $\delta^{18} \mathrm{O}$ of the fluid, the temperature of equilibration, and to a lesser extent, the carbonate mineralogy. Some of the metabasaltic suites, particularly Ubaye and Cignana (see Figs. 3,4), could have been shifted to higher $\delta^{18} \mathrm{O}$ and lower $\delta^{13} \mathrm{C}$ by a C-bearing infiltrating fluid with $\mathrm{XCO}_{2}$ insufficiently low to drive decarbonation reaction (see Fig. 9). As 
667 noted in Section 5.1.2, for many of the metabasalts, the shifts in $\delta^{18} \mathrm{O}$ of whole-rock carbonate

668 (finely disseminated and in small pods and discontinuous veinlets) are consistent with isotopic

669 exchange of the carbonate with the more abundant silicate phases in these rocks, thus seemingly

670 requiring no influence by externally-derived fluids.

$671 \quad 5.2$ Metaultramafic Rocks

672 The highly carbonated metaultramafic rocks (ophicarbonates) investigated here show little

673 or no mineralogical evidence of decarbonation, consistent with the theoretical calculations of

674 Kerrick and Connolly (1998), and in Fig. 10, for prograde reaction in closed systems. Field and

675 petrographic study demonstrates retention of carbonate, for example, with little to no evidence of

676 reaction of carbonate with ultramafic clasts at macro- and micro-scopic scales. In a number of

677 the ophicarbonate exposures, the lack of foliation, retention of breccia cement textures

678 resembling those produced by seafloor alteration, and lack of more through-going veins are

679 consistent with a lack of larger-scale carbonate mobility during subduction. The localization of

680 any subduction-zone deformation along discrete shear zones allows preservation of original

681 breccia textures in more intact and undeformed zones, and the isotopic compositions of these

682 features overlap with those of ophicarbonate produced on the seafloor (see Fig. 5; cf.

683 Schwarzenbach et al., 2013). The wide range of $\mathrm{C}$ and $\mathrm{O}$ isotope compositions for seafloor

684 ophicarbonate (the protoliths) complicates identification of change due to subduction zone

685 metamorphism. However, with the possible exception of the data for the Voltri-Massif and

686 Ubaye, the $\delta^{13} \mathrm{C}$ values do not show obvious evidence for decarbonation (see the typical

687 Rayleigh trend for decarbonation in Fig. 3), supporting the mineralogical evidence for a lack of

688 such reaction. As for some of the metabasalts (e.g., Monviso; see Fig. 4B), the highest-grade

689 ophicarbonates (particularly Zermatt-Saas and Voltri-Massif) show relatively narrow ranges in 
$690 \delta^{18} \mathrm{O}$ that could reflect the influence of a fluid from an external source. Lowering of the $\delta^{13} \mathrm{C}$ of 691 some samples in these suites, particularly Ubaye, hints at either a decarbonation effect or the 692 influence of organic $\mathrm{C}$ in the fluid source, perhaps via exchange with nearby metasedimentary 693 rocks (as for metabasalts from the same locality; see Figs. 3,4C). Ophicarbonates from the 694 lower-grade suites (Bracco, Mt. Fignona, and Ubaye) show wide ranges in $\delta^{18} \mathrm{O}$ perhaps 695 consistent with greater preservation of seafloor alteration signatures. Combining the field, 696 petrographic, isotopic and theoretical evidence, it appears that the ophicarbonates behaved as 697 relatively closed systems, at the high grades perhaps with some episodic infiltration by fluids 698 from external sources insufficient to drive appreciable decarbonation. This implies that a large 699 fraction of the carbonate incorporated into such rocks at/near the seafloor can be retained to great 700 depths in subduction zones, perhaps to $80-90 \mathrm{~km}$.

701 Comparison of our calculations for ophicarbonates with those of Kerrick and Connolly 702 (1998) demonstrates the strong dependence of calculated decarbonation on the rock composition 703 employed in the calculations. Both the calculations in Fig. 10 and by Kerrick and Connolly 704 (1998) indicate that such rocks would largely retain carbonate when subducted along a forearc $P$ $705 T$ gradient such as that represented by our HP/UHP rocks and experienced in many modern 706 subduction zones (example $P$-T paths shown in Fig. 10). However, the further heating at the top 707 of the slab and sediments (to $>600{ }^{\circ} \mathrm{C}$ ) at $80-120 \mathrm{~km}$ depths (see Fig. 10) could result in 708 appreciable decarbonation and the calculations by Kerrick and Connolly (1998) show more 709 dramatic loss of $\mathrm{CO}_{2}$ during this heating than demonstrated in our calculations in Fig. 10. For the 710 composition modeled in Fig. 1A of Kerrick and Connolly (1998), nearly $100 \%$ loss of $\mathrm{CO}_{2}$

711 would be predicted along a $P-T$ path similar to that for N. Vanuatu.

\section{$712 \quad 5.3$ Implications for Deep Subduction-Zone Carbon Cycling}

713 
In this study, as in the studies by Bebout et al. (2013) and Cook-Kollars et al. (2014), focus

715 is placed on understanding devolatilization history of relatively "intact" volumes of lithologies

716 thought to be subducting into modern margins. These exposures contain few through-going,

717 larger vein networks and, for the most part, the metabasalts and ophicarbonates do not show the

718 development of penetrative deformation textures (e.g., containing intact pillow structures). All

719 suggestions are that intact slabs and sediment sections would tend to behave as relatively closed

720 systems except along the more extensive fracture networks and in other particularly deformed

721 zones (e.g., shear zones) that would channelize dehydration-related fluid release (e.g., Zack and

722 John, 2007; John et al., 2012; Konrad-Schmolke and Halama, 2014; Fusseis et al., 2009).

723 A number of authors have proposed relatively closed-system behavior during prograde

724 metamorphism of less-deformed tracts of HP/UHP metabasaltic rocks and many of these studies

725 were focused on metabasalts in the European Alps. Philippot and Selverstone (1991), Barnicoat

726 and Cartwright (1995), Cartwright and Barnicoat (1999), Spandler et al. (2011; these authors

727 suggested some limited open-system behavior), Nadeau et al. (1993), Widmer and Thompson

728 (2001), and Rubatto and Hermann (2003) all invoked relatively local-scale control over fluid

729 composition and little infiltration of mafic meta-ophiolitic rocks by externally-derived fluids (see

730 the discussion by Scambelluri and Philippot, 2001). More recently, Angiboust et al. (2011; 2014)

731 have identified brecciated and sheared domains, within large intact volumes of the Monviso

732 Massif, that likely represent channelways for fluids transported over longer distances. Longer-

733 distance fluid flow through localized fluid conduits in coherent slab sections and at the

734 subduction interface has been proposed for a number of other HP/UHP localities (e.g., Herms et

735 al., 2012, Ecuador; John and Schenk, 2003, Zambia; Gao et al., 2007, Beinlich et al., 2010, John

736 et al., 2012, and Li et al., 2014, Tianshan; Spandler and Hermann, 2006, New Caledonia; 
737 Breeding et al., 2004; Miller et al., 2009, Cyclades; Ague and Nicolescu, 2014, Corsica). This

738 proposed focusing of fluid flow (and related metasomatic alteration) in highly sheared and

739 fractured zones echoes conclusions from study of the Catalina Schist (California), in which

740 metasomatism and isotopic homogenization was enhanced in such zones (Bebout, 1991; Bebout

741 and Barton, 1993; King et al., 2006, 2007) and larger volumes of less permeable, less-deformed

742 metasedimentary and metamafic rock behaved as systems closed to infiltration by externally-

743 derived fluids (Bebout and Fogel, 1992). The extent to which enhanced C loss along these more

744 strongly deformed zones contributes to the overall $\mathrm{C}$ flux from subducting top-slab sections

745 requires further field investigation. The studies of $\mathrm{C}$ mobility along such structures have tended

746 to be conducted on individual or small numbers of exposures and an assessment of the broader

747 significance of such loss will need to be conducted on a more regional scale.

$748 \quad$ Very simply considered, a loss of $10 \%$ of initially subducted C to forearc devolatilization

749 reactions implies delivery of $90 \%$ of this C inventory to depths beneath arcs (global average of

$750105 \mathrm{~km}$; Syracuse and Abers, 2006), where another fraction could be extracted to contribute to

751 arc $\mathrm{CO}_{2}$ degassing and other forearc and mantle wedge $\mathrm{C}$ reservoirs. Loss of another $40 \%$ of the

$752 \mathrm{C}$ beneath arcs would imply that $50 \%$ of the $\mathrm{C}$ could be contributing to mantle regassing on

753 modern Earth. However, this simple comparison overlooks the likely inefficient delivery of any

$754 \mathrm{CO}_{2}$ released from subducting slabs into arc source regions and ultimate return of this $\mathrm{CO}_{2}$ to the

755 atmosphere. Considerable amounts of $\mathrm{C}$ could be transported updip toward the seafloor, along

756 the subduction thrust, or stored in the forearc or subarc mantle wedge.

757 Table 3 provides estimates of extents of closed-system $\mathrm{CO}_{2}$ loss, due to decarbonation

758 reactions, as rocks traverse the $80-120 \mathrm{~km}$ depth range over which further heating occurs (to

$759>600^{\circ} \mathrm{C}$ ). These losses are based on the thermodynamic calculations in Figs. 6-8 and 10 (for 
760

761

762

763

764

765

766

767

768

769

770

771

772

773

774

775

776

777

778

779

780

781

metabasaltic rocks and ophicarbonates) and the calculated $P$ - $T$ paths from Syracuse et al. (2010) for the top of the slab in selected modern Earth subduction zones (Cascadia, Nankai, Northern Vanuatu, and Tonga). Cook-Kollars et al. (2014; see their Supplementary Fig. 3) similarly superimposed these thermal models on the closed-system calculations of Kerrick and Connolly (2001a) for a range of sedimentary compositions from Plank and Langmuir (1998).

The estimates of $\mathrm{CO}_{2}$ loss in Table 3 demonstrate the strong, expected relationship between extents of deep volatiles cycling and subduction-zone thermal structure, the latter related to a number of physical and thermal factors (see discussions of the more recent thermal models by Syracuse et al., 2010; van Keken et al., 2011). For the closed-system model, extensive (perhaps complete) $\mathrm{CO}_{2}$ loss is expected to occur in carbonated basalt and the more mixed clasticcarbonate sediment sections (for the latter, GLOSS and Antilles), whereas ophicarbonate and the more pure carbonate sections (Marianas, Vanuatu) could retain large fractions of their $\mathrm{CO}_{2}$ over this depth range. Here, it is important to recall that subducting altered oceanic crust is believed to convey one-half to two-thirds of the $\mathrm{C}$ entering trenches, on a global basis (see Table 1). The same metabasaltic composition (417A-24) could lose as little as $7 \%$ of its $\mathrm{CO}_{2}$ traversing this same depth range in the very "cool" Tonga margin. It is unlikely that the endmember closedsystem modeling truly approximates decarbonation history at depth in subduction zones, as the limited, evolving permeability of the intact volumes of rocks will afford some pervasive infiltration, and fracture networks are likely to greatly enhance access to the carbonate-bearing sections by $\mathrm{H}_{2} \mathrm{O}$-rich fluids derived elsewhere in the subducting sediment and ophiolitic section (see Fig. 9). Also uncertain is the role of partial melting of various subducting lithologies in mobilizing C beneath arcs (van Keken et al., 2011; Tsuno et al., 2012; discussion by Dasgupta, 
782 2013). Thus, the estimates of $\mathrm{CO}_{2}$ loss in Table 3 provide a crude assessment of the minimum 783 losses expected for such rocks.

An assessment of whether closed-system to limited open-system behavior, as demonstrated here, can result in decarbonation sufficient to balance arc $\mathrm{CO}_{2}$ outputs is further complicated by the poor constraints on volcanic $\mathrm{CO}_{2}$ flux in many individual arcs (see the review by Hilton et al., 787 2002). The most detailed attempt to match subduction $C$ inputs with arc volcanic gas outputs was 788 that of de Leeuw et al. (2007), who suggested that C contributions from the sediments alone 789 could account for the measured output of gases and estimated a sedimentary C return of 12-18\% 790 in Costa Rica and $29 \%$ in El Salvador (i.e., with no contribution of C from the subducting 791 oceanic crust). The calculated $\mathrm{CO}_{2}$ losses in Table 3, for subduction along moderately warm $P-T$ 792 paths such as those at the Central America margin (for Costa Rica and Columbia/El Salvador, 793 very similar to the path for N. Vanuatu; van Keken et al., 2011), are consistent with the proposed $794 \mathrm{CO}_{2}$ returns from subducting sediments in that margin (12-29\%), depending on the exact 795 proportions in that margin of mixed carbonate-clastic sediments undergoing reaction.

796 Interestingly, a slightly larger return of sedimentary $\mathrm{CO}_{2}$ is estimated for the El Salvador margin 797 for which the $P-T$ path is somewhat warmer than that for Costa Rica. However, de Leeuw et al. 798 (2007) provide a discussion of the full range of factors that could control these arc volcanic 799 returns.

800 In addition to decarbonation (and possibly, partial melting), carbonate dissolution, discussed 801 by Ague and Nicolescu (2014; see Caciagli and Manning, 2003; Manning et al., 2013; Manning, 802 2014; cf. John et al., 2008), Frezzotti et al. (2011), and Facq et al. (2014), and conceivably also 803 carbonate reduction (Galvez et al., 2013; Lazar et al., 2014), could mobilize C from slabs, 804 particularly in regions experiencing significant fluid flux (more densely fractured rock volumes, 
shear zones). Greater understanding of the significance of these processes in contributing to C flux from subducting slab+sediment sections also awaits further field and geochemical investigation. Further confounding any quantitative assessment of $\mathrm{C}$ flux from these sections,

808 regardless of the mechanism, is the observation that $\mathrm{C}$ can also be enriched/deposited in some 809 sites, for example, in veins and their envelopes (as both carbonate and graphite; see Bebout, 810 1995; Gao et al., 2007; Beinlich et al., 2010). In this scenario, C is redistributed within 811 subducting slabs and evolving subduction interfaces, but not necessarily removed from these 812 domains and available for addition to the overlying mantle wedge. At shallower levels of 813 forearcs $(<40 \mathrm{~km})$, particularly in paleoaccretionary complexes, this C "capture" is demonstrated 814 by the voluminous carbonate veining and, to a lesser extent, deposition of graphite in veins (see 815 Bebout and Barton, 1993; Bebout, 1995; Sadofsky and Bebout, 2003).

816 A number of other factors can be envisioned as important in dictating $\mathrm{C}$ losses at individual 817 margins, beyond the varying thermal structures, types of sediments, and extents of carbonation in 818 subducting slabs on which we focus in this paper. The thickness of the upper lithospheric plate 819 dictates the depths at which the tops of subducting slabs are heated by exposure to the convecting 820 mantle wedge. Structural state of the incoming oceanic crustal section, and related degrees of 821 seafloor alteration, can be strongly affected by the rates of spreading, with oceanic crust 822 produced by slow spreading (e.g., Atlantic type) tending to be more hydrothermally altered and 823 with gabbros and ultramafic rocks exposed to seawater by large-scale extensional faulting. In the 824 Atlantic Ocean, hydrated and carbonated ultramafic rocks have been recovered by dredging and 825 are believed to be abundant on the modern seafloor (Cannat et al., 1997). As another factor, $\mathrm{CO}_{2}$ 826 contents in oceanic basement can vary with the age of the basement, for example, with Mesozoic 827 basement containing more $\mathrm{CO}_{2}$ than Cenozoic basement reflecting varying atmospheric $\mathrm{CO}_{2}$ 
828 levels (see Alt et al., 2013, and references therein). Finally, modern margins show varying

829 degrees of subduction accretion and erosion (Scholl and von Huene, 2010), in some cases

830 varying along individual margins, and such processes could strongly influence (1) the extent to

831 which parts of the initially subducted sediment section are subducted into the deep forearc and to

832 beneath arcs, and (2) whether large amounts of C-bearing forearc material are entrained to great

833 depths by removal from the hanging wall.

834

835

6. Conclusions and Outlook

836 Following are some conclusions reached in this integrated field, petrologic, and geochemical

837 study and several comments regarding some directions that could be taken in further

838 investigation of metamorphic $\mathrm{C}$ fluxes in subduction zones.

839 - Combining our results with those of Cook-Kollars et al. (2014), it appears that intact volumes

840 of forearc-metamorphosed metabasaltic, meta-ultramafic, and metasedimentary rocks,

841 away from zones of more intense deformation (shear zones, dense fracture networks with

842 through-going veins), could experience only minor amounts of decarbonation, retaining

843 unreacted carbonate with varying textures during prograde metamorphism to depths

844 approaching those beneath volcanic fronts. In metabasalts, the majority of this carbonate

845 likely resides in interpillow regions and breccia matrices, as has been observed for altered

846 oceanic crust recovered during deep-sea drilling (see Gillis and Coogan, 2011). Loss in

847 forearcs of $\mathrm{CO}_{2}$ from ophicarbonates also appears minor based on combination of field

$848 \quad$ results with modeling and isotopic study.

849 - Rocks of these compositions could experience far larger amounts of decarbonation if

850 infiltrated by $\mathrm{H}_{2} \mathrm{O}$-rich fluids (consistent with the modeling results of Kerrick and 
Connolly, 1998, 2001a,b; Connolly, 2005; Gorman et al., 2006). Taking into account the effects of limited open-system behavior, and matching Perple_X calculations with observed changes in mineral modes, Cook-Kollars et al. (2014) estimated 10-20\% loss of $\mathrm{CO}_{2}$ from the Schistes Lustres/Cignana metasedimentary section. Shifts in $\delta^{18} \mathrm{O}$ in some metabasalts, correlated with decrease in $\delta^{13} \mathrm{C}$, and extremely uniform $\delta^{18} \mathrm{O}$ in other suites, could reflect infiltration by $\mathrm{H}_{2} \mathrm{O}$-rich fluids (containing minor $\mathrm{C}$ species) from external sources. subduction zones is expected to be dominantly in sediments, there is some suggestion that deeply subducting metabasaltic rocks could contain significant amounts of reduced C (see Section 4.2) that should be considered in assessments of deep C subduction. Of the three whole-rock analyses of reduced $\mathrm{C}$ presented in this paper, two resemble organic $\mathrm{C}$ in their $\delta^{13} \mathrm{C}$ (near -25\%), and the third resembles the upper mantle, near $-5 \%$. 
— The increased heating of subducting slabs and sediments (to $>600{ }^{\circ} \mathrm{C}$ ) over the approximate depth interval of $80-120 \mathrm{~km}$ (see the $P$ - $T$ paths from Syracuse et al., 2010, and Gerya et al., 2002, in Figs. 6,8A,10) could enhance decarbonation and dissolution and potentially lead to partial melting (van Keken et al., 2011; Tsuno et al., 2012; discussion by Dasgupta, 2013), conceivably resulting in release of $\mathrm{C}$ in quantities sufficient to balance arc outputs.

— Return of slab-released $\mathrm{C}$ to the atmosphere in volcanic arc gases could be quite inefficient large amounts of $\mathrm{C}$ could be stored in the forearc and in the subarc mantle wedge. Greater understanding of this storage is necessary for estimates of the proportion of initially subducted $\mathrm{C}$ entering the deeper mantle (i.e., surviving to depths beyond subarc regions).

— Our work points to the need to investigate $\mathrm{C}$ cycling at individual margins with well-known physical characteristics, including subduction inputs, and thermal structure. Such work might best be done on individual margins for which such parameters are known to vary along strike, providing an analysis of the most important forcing factors (see de Leeuw et al., 2007; House et al., 2014).

\section{Acknowledgements}

Funding for this project came mostly from National Science Foundation grant EAR-1119264 (to GEB). We extend special thanks to James Connolly for his helpful comments and assistance with the use of the Perple_X software, and to Peter van Keken for providing updated calculated $P$ - $T$ paths for modern subduction margins. Rosalind Coggon kindly provided a compilation of the $\mathrm{O}$ and $\mathrm{C}$ isotope compositions of veins in seafloor basalts. MS acknowledges funding from the Italian MIUR (PRIN-COFIN project 2012R33ECR_002). We thank Jeff Alt and an anonymous reviewer for their constructive and useful comments and suggestions. 


\section{References}

900 Agrinier, P., Javoy, M., Smith, D.C., Pineau, F., 1985. Carbon and oxygen isotopes in eclogites, amphibolites, veins and marbles from the Western Gneiss region, Norway. Chem. Geol. 52, 145-162.

902

903

904

905

906

907

908

909

910

911

912

913

914

915

916

917

918

919

920

921

922

923

924

925

926

927

928

929

930

931

932

933

934

935

936

937

938

939

940

941

942

Ague, J.J., Nicolescu, S., 2014. Carbon dioxide released from subduction zones by fluid-mediated reactions. Nature Geosci., DOI: 10.1038/NGEO2143.

Ague, J.J., Rye, D.M., 1999. Simple models of $\mathrm{CO}_{2}$ release from metacarbonates with implications for interpretation of directions and magnitudes of fluid flow in the deep crust. Jour. Petrol. 40, 1443-1462.

Alt, J.C., 2004. 15. Alteration of the upper oceanic crust: mineralogy, chemistry, and processes. in Davis, E.E., Elderfield, H., Hydrogeology of the Oceanic Lithosphere, Cambridge University Press, pp. 497535.

Alt, J.C., Laverne, C., Vanko, D.A., Tartarotti, P., Teagle, D.A., Bach, W., Wilkens, R.H., 1996. Hydrothermal alteration of a section of upper oceanic crust in the eastern equatorial Pacific: A synthesis of results from Site 504 (DSDP Legs 69, 70, and 83, and ODP Legs 111, 137, 140, and 148). Proc. Ocean Drill. Progr. Sci. Res., 417-434.

Alt, J.C., Schwarzenbach, E.M., Fruh-Green, G.L., Shanks III, W.C., Bernasconi, S.M., Garrido, C.J., Crispini, L., Gaggero, L., Padron-Navarta, J.A., Marchesi, C., 2013. The role of serpentinites in cycling of carbon and sulfur: Seafloor serpentinization and subduction metamorphism. Lithos 178, 40-54.

Alt, J.C., Teagle, D.A.H., 2003. Hydrothermal alteration of upper oceanic crust formed at a fast spreading ridge: mineral, chemical, and isotopic evidence from ODP Site 801. Chem. Geol. 201, 191-211.

Alt, J.C., Teagle, D.A.H., Laverne, C., Vanko, D., Bach, W., Honnorez, J., Becker, K., Ayadi, M., and Pezard, P.A., 1996. Ridge flank alteration of upper ocean crust in the eastern Pacific: a synthesis of results for volcanic rocks of holes 504B and 896A. In Proceedings of the Ocean Drilling Program, Scientific Results, Vol. 148, eds. J.C. Alt, H. Kinoshita, L.B. Stokking, and P.J. Michael. College Station, TX: Ocean Drilling Program, pp. 434-452.

Angiboust, S., Agard, P., 2010. Initial water budget: The key to detaching large volumes of eclogitized oceanic crust along the subduction channel? Lithos 120, 453-474.

Angiboust, S., Agard, P., Jolivet, L., Beyssac, O., 2009. The Zermatt-Saas ophiolite: the largest (60 km wide) and deepest (c. 70-80 km) continuous slice of oceanic lithosphere detached from a subduction zone? Terra Nova, 21, 171-180.

Angiboust, S., Agard, P., Raimbourg, H., Yamato, P., Huet, B., 2011. Subduction interface processes recored by eclogite-facies shear zones (Monviso, W. Alps). Lithos 127, 222-238.

Angiboust, S., Langdon, R., Agard, P., Waters, D., Chopin, C., 2012. Eclogitization of the Monviso ophiolite (W. Alps) and implications on subduction dynamics. Jour. Metamorphic Petrol. 30, 37-61.

Angiboust, S., Pettke, T., de Hoog, J.C.M., Caron, B., Oncken, O., 2014. Channelized fluid flow and eclogite-facies metasomatism along the subduction shear zone. Jour. Petrol. 55, 883-916.

Artemyev, D.A., Zaykov, V.V., 2010. The types and genesis of ophicalcites in lower Devonian olistostromes at cobalt-bearing massive sulfide deposits in the West Magnitogorsk paleoisland arc (South Urals). Russ. Geol. Geophys. 51, 750-763.

Barbieri, M., Masi, U., Tolomeo, L., 1979. Stable isotope evidence for a marine origin of ophicalcites from the north-central Apennines (Italy). Mar. Geol. 30, 193-204. doi:10.1016/0025-3227 (79)90015-X.

Barnicoat, A.C., Cartwright, I., 1995. Focused fluid flow during subduction: Oxygen isotope data from high-pressure ophiolites of the western Alps. Earth Planet. Sci. Lett. 132, 53-61. 
961

962

963

964

965

966

967

968

969

970

971

972

973

974

975

976

977

978

979

980

981

982

983

984

985

986

Barrett, T.J., Friedrichsen, H., 1989. Stable isotopic composition of atypical ophiolitic rocks from east Liguria, Italy. Chem. Geol. Isot. Geosci. Sect. 80(1), 71-84. doi: 10.1016/0168-9622(89)90049-3.

Bebout, G.E., 1991. Geometry and mechanisms of fluid flow at 15 to 45 kilometer depths in an early Cretaceous accretionary complex. Geophys. Res. Lett. 18, 923-926.

Bebout, G.E., 1995. The impact of subduction-zone metamorphism on mantle-ocean chemical cycling. Chem. Geol. 126, 191-218.

Bebout, G.E., 2007a. Metamorphic chemical geodynamics of subduction zones. Earth Planet. Sci. Lett. 260, 373-393.

Bebout, G.E., 2007b. Ch. 3.20. Trace element and isotopic fluxes/subducted slab, for Rudnick, R.L., ed., The Crust, Treatise on Geochemistry, Elsevier (eds. K. K. Turekian, H. D. Holland, and R. Rudnick), doi:10.1016/B978-008043751-4/00231-5.

Bebout, G.E., 2013. Chapter 9. Metasomatism in subduction zones of subducted oceanic slabs, mantle wedges, and the slab-mantle interface, in Harlov, D., and Austrheim, H., eds., Metasomatism and the Chemical Transformation of Rock, The Role of Fluids in Terrestrial and Extraterrestrial Processes, Springer-Verlag, pp. 289-349.

Bebout, G.E., 2014. 4.20. Chemical and isotopic cycling in subduction zones, in Rudnick, R. L., ed., The Crust, Treatise on Geochemistry (eds. H. D. Holland and K. K. Turekian, Second Edition), ElsevierPergamon, Oxford, pp. 703-747.

Bebout, G.E., Agard, P., Kobayashi, K., Moriguti, T., Nakamura, E., 2013. Devolatilization history, and related trace element mobility, in deeply subducted sedimentary rocks: SIMS evidence from Western Alps HP/UHP suites. Chem. Geol. 342, 1-20.

Bebout, G.E., Barton, M.D., 1993. Metasomatism during subduction: products and possible paths in the Catalina Schist, California. Chem. Geol. 108, 61-92.

Bebout, G.E., Fogel, M.L., 1992. Nitrogen-isotope compositions of metasedimentary rocks in the Catalina, California - Implications for metamorphic devolatilization history. Geochim. Cosmochim. Acta 56, 2839-2849.

Becker, H., Altherr, R., 1992. Evidence from ultra-high pressure marbles for recycling of sediments into the mantle. Nature 358, 745-748.

Beinlich, A., Klemd, R., John, T., and Gao, J., 2010, Trace-element mobilization during Cametasomatism along a major fluid conduit: Eclogitization of blueschist as a consequence of fluidrock interaction. Geochim. Cosmochim. Acta 74, 1892-1922.

Berner, R.A., 1999. A new look at the long-term carbon cycle. GSA Today 9, 1-6.

Berner, R.A., Lasaga, A.C., Garrels, R.M., 1983. The carbonate-silicate geochemical cycle and its effect on atmospheric carbon dioxide over the past 100 million years. Amer. Jour. Sci. 283, 641-683.

Breeding, C.M., Ague, J.J., Bröcker, M., 2004. Fluid-metasedimentary interactions in subduction zone mélange: implications for the chemical composition of arc magmas. Geology 32, 1041-1044.

Brotzu, P., Ferrini, V., Masi, U., Morbidelli, L., Turi, B., 1973. Contributo alla conoscenza delle «Rocce Verdi» dell'Appennino centrale. Nota III. La composizione isotopica della calcite presente in alcuni affioramenti di oficalciti del F 129 (S. Fiora) e sue implicazioni petrologiche. Period. Mineral. 42, 591-619.

Busigny, V., Cartigny, P., Philippot, P., Ader, M., Javoy, M., 2003. Massive recycling of nitrogen and other fluid-mobile elements ( $\mathrm{K}, \mathrm{Rb}, \mathrm{Cs}, \mathrm{H})$ in a cold slab environment: evidence from HP to UHP oceanic metasediments of the Schistes Lustres nappe (western Alps, Europe). Earth Planet. Sci. Lett. $215,27-42$. 
Caciagli, N.C., Manning, C.E., 2003. The solubility of calcite in water at 6-16 kbar and 500-800 ${ }^{\circ}$ C. Contrib. Mineral. Petrol. 146, 275-285

Cannat, M., Lagabrielle, Y., Bougault, H., Casey, J., De Coutures, N., Dmitriev, L., 1997. Ultramafic and gabbroic exposures at the Mid-Atlantic ridge: geological mapping in the $151 \mathrm{~N}$ region. Tectonophys. $279,197-213$.

Cartwright, I., Barnicoat, A.C., 1999. Stable isotope geochemistry of Alpine ophiolites: a window to ocean-floor hydrothermal alteration and constraints on fluid-rock interaction during high-pressure metamorphism. Int. J. Earth Sci. 88, 219-235.

Cartwright, I. Barnicoat, A.C., 2003. Geochemical and stable isotope resetting in shear zones from Taschalp: constraints on fluid flow during exhumation in the Western Alps. Jour. Metamorphic Geol. 21, 143-161.

Castelli, D., Rolfo, F., Groppo, C., Compagnoni, R., 2007. Impure marbles from the UHP BrossascoIsasca Unit (Dora-Maira Massif, western Alps): evidence for Alpine equilibration in the diamond stability field and evaluation of the $\mathrm{X}\left(\mathrm{CO}_{2}\right)$ fluid evolution. Jour. Metamorphic Geol. 25, 587-603.

Clerc, C., Boulvais, P., Lagabrielle, Y., de Saint Blanquat, M., 2014. Ophicalcites from the northern Pyrenean belt: a field, petrographic and stable isotope study. Int. J. Earth Sci. 103(1), 141-163.

Coggon, R.M., Teagle, D.A.H., Smith-Duque, C.E., Alt, J.C., Cooper, M.J., 2010. Reconstructing past seawater $\mathrm{Mg} / \mathrm{Ca}$ and $\mathrm{Sr} / \mathrm{Ca}$ from mid-ocean ridge flank calcium carbonate veins. Science 327, 11141117.

Connolly, J.A.D., 2005. Computation of phase equilibria by linear programming: a tool for geodynamic modeling and its application to subduction zone decarbonation. Earth Planet. Sci. Lett. 236, 524-541.

Cook-Kollars, J., Bebout, G.E., Collins, N.C., Angiboust, S., Agard, P., 2014. Subduction zone metamorphic pathway for deep carbon cycling: Evidence from HP/UHP metasedimentary rocks, Italian Alps. Chem. Geol., doi: 10.1016/j.chemgeo.2014.07.013.

Dasgupta, R., 2013. Ingassing, storage, and outgassing of terrestrial carbon through geologic time. Mineral. Soc. Amer. Rev. Mineral. Geochem. 75, 183-229.

Dasgupta, R., Hirschmann, M.M., 2010. The deep carbon cycle and melting in Earth's interior. Earth Planet. Sci. Lett. 298, 1-13.

de Leeuw, G.A.M., Hilton, D.R., Fischer, T.P., Walker, J.A., 2007. The He- $\mathrm{CO}_{2}$ isotope and relative abundance characteristics of geothermal fluids in El Salvador and Honduras: New constraints on volatile mass balance of the Central American Volcanic Arc. Earth Planet. Sci. Lett. 258, 132-146.

Demeny, A., Vennemann, T., Koller, F., 2007. Stable isotope compositions of the Penninic ophiolites of the Köszeg-Rechnitz series. Central. Eur. Geol. 50(1), 29-46, doi:10.1556/CEuGeol.50.2007.1.3.

Desmons, J., Aprahamian, J., Compagnoni, R., Cortesogno, L., Frey, M., 1999a. Alpine metamorphism of the Western Alps: I. Middle to high T/P metamorphism. Schweiz. Mineral. Petrogr. Mitt. 79, 89-110.

Desmons, J., Aprahamian, J., Compagnoni, R., Cortesogno, L., Frey, M., 1999b. Alpine metamorphism of the Western Alps: II. High P/T and related pre-greenschist metamorphism. Schweiz. Mineral. Petrogr. Mitt. 79, 111-134.

Ernst, W.G., Dal Piaz, G.V., 1978. Mineral parageneses of eclogitic rocks and related mafic schists of the Piemonte ophiolite nappe, Breuil-St. Jacques area, Italian Western Alps. Amer. Mineral. 63, 621-640.

Evans, C.A., Baltuck, M., 1988. Low-temperature alteration of peridotite, hole 637A. In: Boillot G, Winterer EL et al (ed.) Proc. Ocean Drill. Progr. Sci. Res., 103, 235-239, http://www.odp.tamu.edu/publications/103_SR/103TOC.HTML. 
1030

1031

1032

1033

1034

1035

1036

1037

1038

1039

1040

1041

1042

1043

1044

1045

1046

1047

1048

1049

1050

1051

1052

1053

1054

1055

1056

1057

1058

1059

1060

1061

1062

1063

1064

1065

1066

1067

1068

1069

1070

1071

1072

Facq, S., Daniel, I., Montagnac, G., Cardon, H., Sverjensky, D.A., 2014. In situ Raman study and thermodynamic model of aqueous carbonate speciation in equilibrium with aragonite under subduction zone conditions. Geochim. Cosmochim. Acta 132, 375-390.

Frezzotti, M.L., Huizenga, J.M., Compagnoni, R., Selverstone, J., 2014. Diamond formation by carbon saturation in C-O-H fluids during cold subduction of oceanic lithosphere. Geochim. Cosmochim. Acta, http://dx.doi.org/10.1016/j.gca.2013.12.022.

Frezzotti, M.L., Selverstone, J., Sharp, Z.D., Compagnoni, R., 2011. Carbonate dissolution during subduction revealed by diamond-bearing rocks from the Alps. Nature Geosci. 4, 703-706.

Furnes, H., Muehlenbachs, K., Torsvik, T., Thorseth, I.H., Tumyr, O., 2001. Microbial fractionation of carbon isotopes in altered basaltic glass from the Atlantic Ocean, Lau Basin and Costa Rica Rift. Chem. Geol. 173, 313-330.

Fusseis, F., Regenauer-Lieb, K., Liu, J., Hough, R.M., De Carlo, F., 2009. Creep cavitation can establish a dynamic granular fluid pump in ductile shear zones. Nature 459, 974-977.

Galvez, M.E., Beyssac, O., Martinez, I., Benzerara, K., Chaduteau, C., Malvoisin, B., Malavielle, J., 2013. Graphite formation by carbonate reduction during subduction. Nature Geosci., DOI: 10.1038/NGEO1827.

Gao, J., John, T., Klemd, R., Xiong X., 2007. Mobilization of Ti-Nb-Ta during subduction: evidence from rutile-bearing dehydration segregations and veins hosted in eclogite, Tianshan, NW China. Geochim. Cosmochim. Acta 71, 4974-4996.

Gao, J., Klemd, R., 2003. Formation of HP-LT rocks and their tectonic implications in the western Tianshan Orogen, NW China; geochemical and age constraints. Lithos 66, 1-22.

Gasparik, T., 1989. Experimental study of subsolidus phase relations and mixing properties of pyroxene and plagioclase in the system $\mathrm{Na}_{2} \mathrm{O}-\mathrm{CaO}-\mathrm{Al}_{2} \mathrm{O}_{3}-\mathrm{SiO}_{2}$, Contrib. Mineral. Petrol. 89 346-357.

Gebauer, D., Schertl, H.-P., Brix, M., Schreyer, W., 1997. 35 Ma old ultrahigh-pressure metamorphism and evidence for very rapid exhumation in the Dora Maira massif, Western Alps. Lithos 41, 5-24.

Gerya, T.V., Stockhert, B., Perchuk, A.L., 2002. Exhumation of high-pressure metamorphic rocks in a subduction channel: A numerical simulation. Tectonics 21, doi:10.1029/2002TC001406, 2002.

Gillis, K.M., Coogan, L.A., 2011. Secular variation in carbon uptake into the oceanic crust. Earth Planet. Sci. Lett. 302, 385-392.

Gorman, P.J., Kerrick, D.M., Connolly, J.A.D., 2006. Modeling open system metamorphic decarbonation of subducting slabs. Geochem. Geophys. Geosyst. 7, Q04007, doi:10.1029/2005GC001125.

Groppo, C., Beltrando, M., Compagnoni, R., 2009. The P-T path of the ultra-high pressure Lago di Cignana and adjoining high-pressure meta-ophiolitic units: insights into the evolution of the subducting Tethyan slab. Jour. Metamorphic Geol. 27, 207-231.

Halldorsson, S.A., Hilton, D.R., Troll, V.R., Fischer, T.P., 2013. Resolving volatile sources along the western Sunda arc, Indonesia. Chem. Geol. 339, 263-282.

Herms, P., John, T., Bakker, R.J., Schenk, V., 2012. Evidence for channelized external fluid flow and element transfer in subducting slabs (Raspas Complex, Ecuador). Chem. Geol. 310-311, 79-96.

Hilton, D.R., Fischer, T.P., Marty, B., 2002. Noble gases and volatile recycling at subduction zones. Rev. Mineral. Geochem. 47, 319.

Holland, T., Powell, R., 1991. A Compensated-Redlich-Kwong (CORK) equation for volumes and fugacities of $\mathrm{CO}_{2}$ and $\mathrm{H}_{2} \mathrm{O}$ in the range 1 bar to $50 \mathrm{kbar}$ and $100-1600{ }^{\circ} \mathrm{C}$. Contrib. Mineral. Petrol. 109, 265-273. 
1073

1074

1075

1076

1077

1078

1079

1080

1081

1082

1083

1084

1085

1086

1087

1088

1089

1090

1091

1092

1093

1094

1095

1096

1097

1098

1099

1100

1101

1102

1103

1104

1105

1106

1107

1108

1109

1110

1111

1112

1113

1114

1115

1116

Holland, T.J.B., Powell, R., 1998. An internally consistent thermodynamic data set for phases of petrological interest. Jour. Metamorphic Geol. 16, 309-343.

House, B.M., Bebout, G.E., Hilton, D.R., Rodriguez, B., Plank, T., 2014. Constraining sources of subducted and recycled carbon along the Sunda Arc (abstract), Amer. Geophys. Un. Ann. Meeting, San Francisco, December, 2014.

Jarrard, R.D., 2003. Subduction fluxes of water, carbon dioxide, chlorine, and potassium. Geochem. Geophys. Geosyst. 5; doi:10.1029/2002GC000392.

Javoy, M.,1998. The birth of the Earth's atmosphere: the behaviour and fate of its major elements. Chem. Geol. 147, 11-25.

Jedrysek, M.O., Weber-Weller, A., Szynkiewicz, A., Mierzejewski, M., 2000, Evolution of Sleza and Nowa Ruda Ophiolites: Oceanic and Continental Stages Recorded in Stable Isotope Composition of Oxides, Carbonates and Sulphides. GeoLines (Praha) 10.

Joesten, R., 1977. Evolution of mineral assemblage zoning in diffusion metasomatism. Geochim. Cosmochim. Acta 41, 649-670.

John, T., Gussone, N., Podladchikov, Y.Y., Bebout, G.E., Dohmen, R., Halama, R., Klemd, R., Magna, T., Seitz, H.M., 2012. Volcanic arcs fed by rapid pulsed fluid flow through subducting slabs, Nature Geosci. 5, 489-492.

John, T., Klemd, R., Gao, J., Garbe-Schonberg, C.D., 2008, Trace-element mobilization in slabs due to non steady-state fluid-rock interaction: constraints from an eclogite-facies transport vein in blueschist (Tianshan, China). Lithos 103, 1-24.

John, T., Schenk, V., 2003. Partial eclogitisation of gabbroic rocks in a late Precambrian subduction zone (Zambia): prograde metamorphism triggered by fluid infiltration. Contrib. Mineral. Petrol. 146, 174191.

Jolivet, L., Faccena, C., Goffe, B., Burov, E., Agard, P., 2003. Subduction tectonics and exhumation of high-pressure metamorphic rocks in the Mediterranean orogens. Amer. Jour. Sci. 303, 353-409.

Kato, T., Enami, M. Zhai, M., 1997. Ultra-high-pressure (UHP) marble and eclogite in the Su-Lu UHP terrane, eastern China. Jour. Metamorphic Geol. 15, 169-182.

Kerrick, D.M., 2001. Present and past nonanthropogenic $\mathrm{CO}_{2}$ degassing from the solid Earth. Rev. Geophys. 39, 565-585.

Kerrick, D.M., Connolly, J.A.D., 1998. Subduction of ophicarbonates and recycling of $\mathrm{CO}_{2}$ and $\mathrm{H}_{2} \mathrm{O}$. Geology 26, 375-378.

Kerrick, D.M., Connolly, J.A.D., 2001a. Metamorphic devolatilization of subducted marine sediments and the transport of volatiles into the Earth's mantle. Nature 411, 293-296.

Kerrick, D.M., Connolly, J.A.D., 2001b. Metamorphic devolatilization of subducted oceanic metabasalts: implications for seismicity, arc magmatism and volatile recycling. Earth Planet. Sci. Lett. 189, 19-29.

King, R.L., Bebout, G.E., Grove, M., Moriguti, T., Nakamura, E., 2007. Boron and lead isotope signatures of subduction-zone melange formation: Hybridization and fractionation along the slabmantle interface beneath volcanic arcs. Chem. Geol. 239, 305-322.

King, R.L., Bebout, G.E., Kobayashi, K., Nakamura, E., van der Klauw, S.N.G.C., 2004. Ultrahighpressure metabasaltic garnets as probes into deep subduction zone chemical cycling. Geochem. Geophys. Geosyst., Q12J14, doi:10.1029/2004GC000746.

King, R.L., Bebout, G.E., Moriguti, T., Nakamura, E., 2006. Elemental mixing systematics and Sr-Nd isotope geochemistry of mélange formation: Obstacles to identification of fluid sources to arc volcanics. Earth Planet. Sci. Lett. 246, 288-304. 
Klemd, R., Schroter, F.C., Will, T.M. Gao, J., 2002. P-T evolution of glaucophane-omphacite bearing HP-LT rocks in the western Tianshan Orogen, NW China; new evidence for "Alpine-type" tectonics. Jour. Metamorphic Geol. 20, 239-254.

Klemd, R., Bröcker, M., Hacker, B.R., Gao, J., Gans, P., Wemmer, K., 2005. New age constraints on the metamorphic evolution of the high-pressure/low-temperature belt in the western Tianshan Mountains, NW China. Jour. Geol. 113, 157-168.

Klemd, R., John, T., Scherer, E.E., Rondenay, S., Gao, J., 2011. Changes in dip of subducted slabs at depth: Petrological and geochronological evidence from HP-UHP rocks (Tianshan, NW-China). Earth Planet. Sci. Lett., 310, 9-20.

Konrad-Schmolke, M., Halama, R., 2014. Combined thermodynamic-geochemical modeling in metamorphic geology: Boron as tracer of fluid-rock interaction. Lithos 208-209, 393-414.

Lagabrielle, Y., Cannat, M., 1990. Alpine Jurassic ophiolites resemble the modern central Atlantic basement. Geology 18, 319-322.

Lavoie, D., Cousineau, P.A., 1995. Ordovician ophicalcites of southern Quebec Appalachians: a proposed early seafloor tectonosedimentary and hydrothermal origin. Jour. Sediment. Res. 65(2a), 337-347.

Lazar, C., Zhang, C., Manning, C.E., Mysen, B.O., 2014. Redox effects on calcite-portlandite-fluid equilibria at forearc conditions: Carbon mobility, methanogenesis, and reduction melting of calcite. Amer. Mineral. 99, 1604-1615.

Leoni, L., Marroni, M., Sartori, F., Tamponi, M., 1996. Metamorphic grade in metapelites of the internal liguride units (Northern Apennines, Italy). Eur. J. Min. 8(1), 35-50.

Li, L., Bebout, G.E., 2005. Carbon and nitrogen geochemistry of sediments in the Central American convergent margin: Insights regarding subduction input fluxes, diagenesis, and paleoproductivity. Jour. Geophys. Res. 110, B11202.

Lu, Z., Zhang, L., Chen, Z., 2014. Jadeite- and dolomite-bearing coesite eclogite from western Tianshan, NW China. Eur. J. Mineral. 26, 245-256.

Manning, C.E., 2014. A piece of the deep carbon puzzle (News \& Views). Nature Geosci., April 20, 2014.

Manning, C.E., Shock, E.L., Sverjensky, D.A., 2013. The chemistry of carbon in aqueous fluids at crustal and upper-mantle conditions: Experimental and theoretical constraints. Mineral. Soc. Amer. Rev. Mineral. Geochem. 75, 109-148.

Marin-Ceron, M.I., Moriguti, T., Makishima, A., Nakamura, E., 2010. Slab decarbonation and $\mathrm{CO}_{2}$ recycling in the Southwestern Colombian volcanic arc. Geochim. Cosmochim. Acta 74, 1104-1121.

Martin, S., Rebay, G., Kienast, J.-R., Mevel, C., 2008. An eclogitised oceanic paleohydrothermal field from the St. Marcel Valley (Italian Western Alps). Ofioliti 33, 49-63.

Martin, S., Tartarotti, P., 1989. Polyphase HP Metamorphism in the ophiolitic gaucophanites of the Lower St. Marcel Valley (Aosta, Italy). Ofioliti 14. 135-156.

Marty, B., Tolstikhin, I.N., 1998. $\mathrm{CO}_{2}$ fluxes from mid-ocean ridges, arcs and plumes. Chem. Geol. 145, 233-248.

Michard, A., Avigad, D., Goffe, B., Chopin, C., 2004. The high-pressure metamorphic front of the south Western Alps (Ubaye-Maira transect, France, Italy). Schweiz. Mineral. Petrogr. Mitt. 84, 215-235.

Miller, J.A., Cartwright, I., 2000. Distinguishing between seafloor alteration and fluid flow during subduction using stable isotope geochemistry: examples from Tethyan ophiolites in the Western Alps. Jour. Metamorphic Geol. 8, 467-482.

Miller, J.A., Cartwright, I., Buick, I.S. Barnicoat, A.C., 2001. An O-isotope profile through the HP-LT Corsican ophiolite, France and its implications for fluid flow during subduction. Chem. Geol. 178, 43-69. 
Miller, D.P., Marschall, H.R., Schumacher, J.C., 2009. Metasomatic formation and petrology of blueschist-facies hybrid rocks from Syros (Greece): Implications for reactions at the slab-mantle interface, Lithos 107, 53-67.

Milliken, K.L., Morgan, J.K., 1996. Chemical evidence for near-seafloor precipitation of calcite in serpentinites (site 897) and Serpentinite Breccias (Site 899), Iberia Abyssal Plain. In: Whitmarsh RB, Sawyer DS, Klaus A, Masson DG (eds) Proceedings of the ocean drilling program, 149 scientific results, vol. 149, Ocean Drilling Program, pp. 553-558, http://wwwodp.tamu.edu/publications/149_SR/149TOC.HTML

Molina, J. F., and Poli, S., 2000. Carbonate stability and fluid composition in subducted oceanic crust: an experimental study on $\mathrm{H}_{2} \mathrm{O}-\mathrm{CO}_{2}$-bearing basalts. Earth Planet. Sci. Lett. 176, 295-310.

Nadeau, S., Philippot, P. Pineau, F., 1993. Fluid inclusion and mineral isotopic compositions (H-C-O) in eclogitic rocks as tracers of local fluid migration during high-pressure metamorphism. Earth Planet. Sci. Lett. 114, 431-448.

Parrish, R.R., Gough, S.J., Searle, M.P., Waters, D.J., 2006. Plate velocity exhumation of ultra-high pressure eclogites in the Pakistan Himalaya. Geology 34, 989-992.

Pelletier, L., Muntener, O., Kalt, A., Vennemann, T.W., Belgya, T., 2008. Emplacement of ultramafic rocks into the continental crust monitored by light and other trace elements: An example from the Geisspfad body (Swiss-Italian Alps). Chem. Geol. 255, 143-159.

Penniston-Dorland, S.C., Kohn, M.J., Manning, C.E., 2014. Exhumed blueschists and eclogites: hotter than the average model. Abstract V24C-06, Amer. Geophys. Union Fall Meeting.

Penniston-Dorland, S.C., Kohn, M.J., Manning, C.E., in press. The global range of subduction zone thermal structures from exhumed blueschists and eclogites: Rocks are hotter than models. Earth Planet. Sci. Lett.

Philippot, P., 1993. Fluid-melt-rock interaction in mafic eclogites and coesite-bearing metasediments: constraints on volatile.recycling during subduction. In: J.L.R. Touret and A.B. Thompson (GuestEditors), Fluid-Rock Interaction in the Deeper Continental Litbosphl:re. Chem. Geol. 108, 93-112 (special issue).

Philippot, P., Selverstone, J., 1991. Trace element-rich brines in eclogitic veins: implications for fluid composition and transport during subduction. Contrib. Mineral. Petrol. 106, 417-430.

Plank T., 2014, 4.19. The chemical composition of subducting sediments, in Rudnick, R.L. (Ed.), The Crust, Treat. Geochem., 2nd edition, v. 4, Elsevier.

Plank, T., Langmuir, C.H., 1998. The chemical composition of subducting sediment and its consequences for the crust and mantle. Chem. Geol. 145, 325-394.

Plas, A., 1997. Petrologic and stable isotope constraints on fluid-rock interaction, serpentinization and alteration of oceanic ultramafic rocks. PhD Thesis, Swiss Federal Institute of Technology.

Platt, J.P., 1986. Dynamics of orogenic wedges and the uplift of high-pressure metamorphic rocks. Geol. Soc. Amer. Bull. 97, 1037-1053.

Poli, S., Franzolin, E., Fumagalli, P., Crottini, A., 2009. The transport of carbon and hydrogen in subducted oceanic crust: An experimental study to 5 GPa. Earth Planet. Sci. Lett. 278, 350-360.

Proyer, A., 2003. Metamorphism of pelites in NKFMASH - a new petrogenetic grid with implications for the preservation of high-pressure mineral assemblages during exhumation. Jour. Metamorphic Geol. 21, 493-509.

Proyer, A., Rolfo, F., Castelli, D., Compagnoni, R., 2014. Diffusion-controlled metamorphic reaction textures in an ultrahigh-pressure impure calcite marble from Dabie Shan, China. Eur. J. Mineral. 26, 25-40. 
Ranero, C.R., Villasenor, A., Phipps Morgan, J., Weinrebe, W., 2005. Relationship between bend-faulting at trenches and intermediate-depth seismicity. Geochem. Geophys. Geosyst. 6, Q12002, doi:10.1029/2005GC000997.

Reinecke, T., 1998. Prograde high- to ultrahigh-pressure metamorphism and exhumation of oceanic sediments at Lago di Cignana, Zermatt-Saas Zone, western Alps. Lithos 42, 147-189.

Rubatto, D., Gebauer, D., Fanning, M., 1998. Jurassic formation and Eocene subduction of the ZermattSaas-Fee ophiolites: implications for the geodynamic evolution of the Central and Western Alps. Contrib. Mineral. Petrol. 132, 269-287.

Rubatto, D., Hermann, J., 2001. Exhumation as fast as subduction? Geology 29, 3-6.

Rubatto, D., Hermann, J., 2003. Zircon formation during fluid circulation in eclogites (Monviso, Western Alps): implications for $\mathrm{Zr}$ and $\mathrm{Hf}$ budget in subduction zones. Geochim. Cosmochim. Acta 67, 21732187.

Sadofsky, S.J., Bebout, G.E., 2003. Record of forearc devolatilization in low-T, high-P/T metasedimentary suites: significance for models of convergent margin chemical cycling, Geochem. Geophy. Geosyst. 4, 9003, doi:10.1029/2002GC000412.

Sano, Y., Williams, S.N., 1996. Fluxes of mantle and subducted carbon along convergent margins. Geophys. Res. Lett. 23, 2749-2752.

Sano, Y., Takahata, N., Nishio, Y., Fischer, T.P., Williams, S.N., 2001. Volcanic flux of nitrogen from the Earth. Chem. Geol. 171, 263-271.

Scambelluri, M., Malaspina, N., Hermann, J., 2007. Subduction fluids and their interaction with the mantle wedge: a perspective from the study of high-pressure ultramafic rocks. Periodico di Mineralogia 76, 253-265.

Scambelluri, M., Muntener, O., Ottolini, L., Pettke, T., Vannucci, R., 2004. The fate of B, Cl, and Li in the subducted oceanic mantle and in the antigorite breakdown fluids. Earth Planet. Sci. Lett. 222, 217-234.

Scambelluri, M., Philippot, P., 2001. Deep fluids in subduction zones. Lithos 55, 213-227.

Schmidt, M.W., Poli, S., 2014. 4.19. Devolatilization during subduction, in Rudnick, R. L., ed., The Crust, Treatise on Geochemistry (eds. H. D. Holland and K. K. Turekian, Second Edition), ElsevierPergamon, Oxford, pp. 669-701.

Scholl, D.W., von Huene, R., 2010. Subduction zone recycling processes and the rock record of crustal suture zones. Can. Jour. Earth Sci. 47, 633-654.

Schwarzenbach, E.M., Fruh-Green, G.L., Bernasconi, S.M., Alt, J.C., Plas, A., 2013. Serpentinization and carbon sequestration: A study of two ancient peridotite-hosted hydrothermal systems. Chem. Geol. $351,115-133$.

Shaw, A.M., Hilton, D.R., Fischer, T.P., Walker, J.A., Alvarado, G.E., 2003. Contrasting He-C relationships in Nicaragua and Costa Rica: insights into $\mathrm{C}$ cycling through subduction zones. Earth Planet. Sci. Lett. 214, 499-513.

Sheppard, S.M.F., Schwarcz, H.P., 1970. Fractionation of carbon and oxygen isotopes and magnesium between coexisting metamorphic calcite and dolomite. Contrib. Mineral. Petrol. 26, 161-198.

Skelton, A.D., Valley, J.W., 2000. The relative timing of serpentinisation and mantle exhumation at the ocean-continent transition, Iberia: constraints from oxygen isotopes. Earth. Planet. Sci. Lett. 178, 327-338.

Spandler, C., Hermann, J., 2006. High-pressure veins in eclogite from New Caledonia and their significance for fluid migration in subduction zones. Lithos 89, 135-153. 
Spandler, C., Pettke, T., Rubatto, D., 2011. Internal and external fluid sources for eclogite-facies veins in the Monviso meta-ophiolite, Western Alps: Implications for fluid flow in subduction zones. Jour. Petrol. 52, 1207-1236.

Staudigel, H., Hart, S.R., Schmincke, H.U., Smith, B.M., 1989. Cretaceous ocean crust at DSDP Sites 417 and 418: Carbon uptake from weathering versus loss by magmatic outgassing. Geochim. Cosmochim. Acta 53, 3091-3094.

Staudigel, H., Plank, T., White, B., Schmincke, H.U., 1996. Geochemical fluxes during seafloor alteration of the basaltic upper oceanic crust: DSDP Sites 417 and 418. in Bebout, G.E., Scholl, D.W., Kirby, S.H., Platt, J.P., eds., Subduction Top to Bottom, Amer. Geophys. Un. Geophys. Monogr. 96, 19-38.

Syracuse, E.M., Abers, G.A., 2006. Global compilation of variations in slab depth beneath arc volcanoes and implications. Geochem. Geophys. Geosyst. Q05017, doi:10.1029/2005GC001045.

Syracuse, E.M., van Keken, P.E., Abers, G.A., 2010. The global range of subduction zone thermal models. Phys. Earth Planet. Int. 183, 73-90.

Thompson, A.B., 1975. Calc-silicate diffusion zones between marble and pelitic schist. Jour. Petrol. 16, 314-346.

Tricart, P., Lemoine, M., 1986. From faulted blocks to megamullions and megaboudins: Tethyan heritage in the structure of the Western Alps. Tectonics 5, 95-118.

Tricart, P., Lemoine, M., 1991. The Queyras ophiolite west of Monte Viso (Western Alps): indicator of a peculiar ocean floor in the Mesozoic Tethys. Jour. Geodynam. 13, 163-181.

Tsuno, K., Dasgupta, R., 2011. Melting phase relation of nominally anhydrous, carbonated peliticeclogite at 2.5-3.0 GPa and deep cycling of sedimentary carbon. Contrib. Mineral. Petrol. 161, 743763.

Tsuno, K., Dasgupta, R., Danielson, L., Righter, K., 2012. Flux of carbonate melt from deeply subducted pelitic sediments: Geophysical and geochemical implications for the source of Central American volcanic arc. Geophys. Res. Lett. 39, doi:10.1029/2012GL052606.

Valley, J.W., 1986. Stable isotope geochemistry of metamorphic rocks. Rev. Mineral. Geochem. 16, 445489.

Vallis, F., Scambelluri, M., 1996. Redistribution of high-pressure fluids during retrograde metamorphism of eclogite-facies rocks (Voltri Massif, Italian Western Alps). Lithos 39, 81-92.

van der Meer, D.G., Zeebe, R.E., van Hinsbergen, D.J.J., Sluijs, A., Spakman, W., Torsvik, T.H., 2014. Plate tectonic controls on atmospheric $\mathrm{CO}_{2}$ levels since the Triassic. Proc. National Acad. Sci. 111, 4380-4385.

van der Klauw, S.N.G.C., 1998. Exhumation of ultrahigh-pressure metamorphic oceanic crust from Lago di Cignana, Piemontese zone, western Alps: the structural record in metabasites. PhD Thesis, RuhrUniversität Bochum.

van der Klauw, S.N.G.C., Reinecke, T., Stockhert, B., 1997. Exhumation of ultrahigh-pressure metamorphic oceanic crust from Lago di Cignana, Piemontese zone, western Alps: the structural record in metabasites. Lithos 41, 79-102.

van der Straaten, F., Schenk, V., John, T., Gao, J., 2008. Blueschist-facies rehydration of eclogites (Tian Shan, NW-China): Implications for fluid-rock interaction in the subducted channel. Chem. Geol. 255, 195-219.

van der Straaten, F., Halama, R., John, T., Schenk, V., Hauff, F., Andersen, N., 2012. Tracing the effects of high-pressure metasomatic fluids and seawater alteration in blueschist-facies overprinted eclogites: Implications for subduction channel processes. Chem. Geol. 292, 69-87. 
van Keken, P.E., Hacker, B.R., Syracuse, E.M., Abers, G.A., 2011. Subduction factory: 4. Depthdependent flux of $\mathrm{H}_{2} \mathrm{O}$ from subducting slabs worldwide. Jour. Geophys. Res. 116, B01401, doi:10.1029/2010JB007922.

Vignaroli, G., Rossetti, F., Bouybaouene, M., Massonne J., Theye, T., Faccenna, C., Funiciello, R., 2005, A counter-clockwise P-T path for the Voltri Massif eclogites (Ligurian Alps, Italy). Jour. Metamorphic Geol. 23, 533-555.

Wei, C., Powell, R., 2003. Phase relations in high-pressure metapelites in the system KFMASH $\left(\mathrm{K}_{2} \mathrm{O}-\right.$ $\mathrm{FeO}-\mathrm{MgO}-\mathrm{Al}_{2} \mathrm{O}_{3}-\mathrm{SiO}_{2}-\mathrm{H}_{2} \mathrm{O}$ ) with application to natural rocks. Contrib. Mineral. Petrol. 145, 301-315.

Wei, C., Powell, R., Zhang, L., 2003. Eclogites from the south Tianshan, NW China: petrological characteristic and calculated mineral equilibria in the $\mathrm{Na}_{2} \mathrm{O}-\mathrm{CaO}-\mathrm{FeO} \mathrm{MgOAl}{ }_{2} \mathrm{O}_{3}-\mathrm{SiO}_{2}-\mathrm{H}_{2} \mathrm{O}$ system. Jour. Metamorphic Geol. 21, 163-179.

Weissert, H., Bernoulli, D., 1984. Oxygen isotope composition of calcite in Alpine ophicarbonates: a hydrothermal or Alpine metamorphic signal? Eclogae. Geol. Helv. 77(1), 29-43.

Whitney, D.L., Evans, B.W., 2010. Abbreviations for names of rock-forming minerals. Amer. Mineral. 95(1), 185.

Widmer, T., Thompson, A.B., 2001. Local origin of high pressure vein material in eclogite facies rocks of the Zermatt-Saas Zone, Switzerland. Amer. Jour. Sci. 301, 627-656.

Zack, T., John, T., 2007. An evaluation of reactive fluid flow and trace element mobility in subducting slabs. Chem. Geol. 239, 199-216.

Zhang, Y., Zindler, A., 1993. Distribution and evolution of carbon and nitrogen in Earth. Earth Planet. Sci. Lett. 117(3), 331-345.

Zheng, Y.-F., 1993. Calculation of oxygen isotope fractionation in anhydrous silicate minerals. Geochim. Cosmochim. Acta 57, 1079-1091.

Zheng, Y.-F., 2012. Metamorphic chemical geodynamics in continental subduction zones. Chem. Geol. 328, 5-48, doi:10.1016/j.chemgeo.2012.02.005.

Zheng, Y.-F., Fu, B., Gong, B., Li, L., 2003. Stable isotope geochemistry of ultrahigh pressure metamorphic rocks from the Dabie-Sulu orogen in China: implications for geodynamics and fluid regime. Ear.-Sci. Rev. 62, 105-161.

Zimmer, M.M., Fischer, T.P., Hilton, D.R., Alvarado, G.E., Sharp, Z.D., Walker, J.A., 2004. Nitrogen systematics and gas fluxes of subduction zones: Insights from Costa Rica arc volatiles. Geochem. Geophy. Geosyst. 5, Q05J11, doi:10.1029/2003GC000651.

\section{Figure Captions}

Figure 1. (A) Generalized geologic map for the Western Alps detailing sample locations. See Supplementary Table 1 for coordinates of sampling locations. (B) Pressure-temperature diagram showing peak $P-T$ for the field localities and the $P-T$ gradient defined by these units. $P-T$ estimates for these locations are from Leoni et al. (1996), Michard et al. (2004), Angiboust et al. (2012), Vignaroli et al. (2005), Angiboust and Agard (2010), Groppo et al. (2009), and Frezzotti et al. $(2011,2014)$. Units for Monviso are denoted with LS for the Lago Superiore Unit and MV for the Monviso Unit.

Figure 2: Field photographs of pillow basalts with representative textures, all but $(\mathbf{C})$ with a $35 \mathrm{~mm}$ camera lens for scale. (A) Undeformeed prenhite-pumpellyite facies pillow basalts 
from the Bracco Unit. (B) Eclogite facies pillow basalt from the Lago Superiore Unit at Monviso. (C) Deformed meta-pillow basalts at the Lago di Cignana locality (horizontal dimension $\sim 1 \mathrm{~m}$ ). (D) Breccia containing clasts of metagabbro in a largely calcite matrix at the Bracco Unit exposure.

Figure 3: $\delta^{13} \mathrm{C}$ and $\delta^{18} \mathrm{O}$ for all of carbonate sampled from all textural settings within the metabasalts (data in Supplementary Table 2). The lower unfilled box on the right side of the plot illustrates the range of values for finely disseminated calcite in seafloor-altered basalts (from Furnes et al., 2001). The upper unfilled box shows the $\delta^{18} \mathrm{O}$ range possible for carbonate veins in variably seafloor-altered basalts (from Alt and Teagle, 2003; Coggon et al., 2010; J. Alt and R. Coggon, personal communication, 2014). Also included are data for veins and breccia fillings in metabasalt from Catalina Schist from Bebout (1995). The curved line labeled "Rayleigh Trend" is the trend in $\delta^{13} \mathrm{C}$ and $\delta^{18} \mathrm{O}$ for closed-system decarbonation approximating a Rayleigh process (i.e., generation and loss of fluid without addition of fluid from external sources). The exact curve length (i.e., decrease in $\delta^{13} \mathrm{C}$ possible, related to the fraction of $\mathrm{C}$ remaining in the Rayleigh calculation) and the trajectory taken depend on the initial modal abundances of the carbonate and silicate phases and the reactions that take place (the latter producing change in mineral modes). Whole-rock $\delta^{18} \mathrm{O}$ values for seafloor-altered oceanic crust are as high as $+20 \%$ but most are in the range of +5 to $+10 \%$ (Alt, 2004). The arrow labeled, "Exchange with $\mathrm{H}_{2} \mathrm{O}$-rich Fluid," indicates the $\delta^{18} \mathrm{O}$ shifts that carbonate in metabasalts would experience as influenced by exchange with $\mathrm{H}_{2} \mathrm{O}$-rich fluid containing little or no $\mathrm{C}$ (depending on temperature and the $\delta^{18} \mathrm{O}$ of the fluids).

Figure 4: Carbon and $\mathrm{O}$ isotope plots for select localities divided by textural occurrence of carbonates. (A) Bracco and Mt. Fignona Units; (B) Monviso (Monviso Unit and Lago Supierore Unit); (C) Ubaye Unit, France, and (D) Zermatt-Saas and Lago di Cignana.

Figure 5: Isotopic compositions of the ophicarbonates (modified from Clerc et al., 2014; data in Supplementary Table 2). Shaded grey areas and lightly shaded grey symbols represent values from the literature for ophicalcites from the low-temperature Iberian margin and Galicia Bank (Evans and Baltuck, 1988; Milliken and Morgan, 1996; Plas, 1997; Skelton and Valley, 2000), the Alps, Apennines, and Pyrenees (Brotzu et al., 1973; Barbieri et al., 1979; Weissert and Bernoulli, 1984; Barrett and Friedrichsen, 1989; Demeny et al., 2007; Clerc et al., 2014), and from other high-temperature hydrothermal ophicalcites (Lavoie and Cousineau, 1995; Artemyev and Zaykov, 2010; Jedrysek et al., 2000).

Figure 6: Pseudosections calculated with Perple_X for different basalt compositions with $P-T$ paths from four modern subduction zones (dashed white lines) from van Keken et al. (2011). $\mathrm{T}=$ Tonga, $\mathrm{NV}=\mathrm{N}$. Vanuatu, $\mathrm{N}=$ Nankai, and $\mathrm{C}=$ Cascadia. Basaltic compositions are from Staudigel et al. (1989), Alt et al. (1996), Staudigel et al. (1996), and King et al. (2004), and are provided in Supplementary Table 4. Mineral abbreviations are from Whitney and Evans (2010) with the exception of the combined carbonate phases (Carb). Note the very different starting $\mathrm{CO}_{2}$ concentrations in these compositions. A recent comparison of peak-pressure $P-T$ conditions for HP/UHP suites with recently published thermal models, by Penniston-Dorland et al. (2014, in press), indicates that the $P$ - $T$ paths calculated by Gerya et al. (2002) for forearcs could be more compatible with the field metamorphic record than those of Syracuse et al. (2010). However, the models of both Gerya et al. (2002) and Syracuse et al. (2010) compare reasonably well with the array of peak $P-T$ for the W. Alps forearc units investigated in this study and by Cook-Kollars et al. (2014). The two thermal modeling 
studies similarly indicate top-slab temperatures $>600^{\circ} \mathrm{C}$ at depths of $80-120 \mathrm{~km}$ (see the discussion in Section 5.3).

Figure 7: Mineral modal abundances calculated with Perple_X for four modern day subduction zones using the average composition of ODP 417/418 (see the pseudosection for this composition in Fig. 6C). $\mathbf{A}=$ Tonga; $\mathbf{B}=\mathrm{N}$. Vanuatu; $\mathbf{C}=$ Nankai; $\mathbf{D}=$ Cascadia. In these figures, the $\mathrm{x}$ axis indicates pressure increase to the right (and corresponding temperature increase) along the $P-T$ paths for these margins shown in Figs. 6, 8a, and 10.

Figure 8. (A) Volatiles isopleth diagram of a composition from ODP Site 417/418 (Staudigel et al., 1996) containing a relatively high $\mathrm{H}_{2} \mathrm{O}$ content. Dashed grey lines represent $\mathrm{H}_{2} \mathrm{O}$ content and solid black lines represent the $\mathrm{CO}_{2}$ content. Solid grey lines display $P-T$ paths for four modern day subduction zones (Syracuse et al, 2010; van Keken et al., 2011) and are labeled the same as Figs. 6C and 7. Blue boxes represent the $P$ - $T$ estimates of the sites sampled in this study. (B) Closed-system devolatilization of the average composition from ODP 417/418 (Staudigel et al., 1996) across three modern day subduction zones (Tonga [cool], N. Vanuatu [intermediate], and Cascadia [warm]; see A). These $P-T$ paths were taken from Syracuse et al. (2010) and van Keken et al. (2011; P. van Keken, personal communication, 2013). Light grey-shaded area represents metabasalts investigated in this study. The dark grey-shaded area represents the global average of modern day sub-arc depths.

Figure 9: $\mathrm{T}-\mathrm{X}_{\mathrm{CO}_{2}}$ diagrams from the average basaltic composition of ODP 417/418 (composition from Staudigel et al., 1996; see Supplementary Table 4). Panel A shows the compositions at $15 \mathrm{kbar}$ and Panel B shows compositions at $25 \mathrm{kbar}$. Panels 1-2 detail the modal abundance changes that would occur in Panel A with the infiltration of an $\mathrm{H}_{2} \mathrm{O}$-rich fluid at two different temperatures. Panels 3-4 detail the modal abundance changes that would occur in Panel B with the infiltration of an $\mathrm{H}_{2} \mathrm{O}$-rich fluid at two different temperatures.

Figure 10: Volatiles isopleth diagram for an ophicarbonate composition (carbonated serpentinite) initially containing 5.5 wt. $\% \mathrm{CO}_{2}$ and $11.0 \mathrm{wt} . \% \mathrm{H}_{2} \mathrm{O}$ (composition modeled is based on sample G4 in Table 2 of Pelletier et al., 2008). Although such rocks experience significant dehydration over the $550-800^{\circ} \mathrm{C}$ temperature range, relatively little $\mathrm{CO}_{2}$ is lost and even the warmest of the $P-T$ paths (Cascadia) results in only $\sim 15 \%$ loss. Based on somewhat different bulk compositions, the calculations of Kerrick and Connolly (1998), with the $P-T$ paths of Syracuse et al. (2010) superimposed, similarly indicate near-complete $\mathrm{CO}_{2}$ retention in forearcs. However, relative to our calculations, the calculations by these authors indicate considerably higher (near complete) $\mathrm{CO}_{2}$ losses along these more recently published paths for the depth interval of $80-120 \mathrm{~km}$. The $\mathrm{C}$ input into subduction zones in this lithology is highly uncertain, with the estimates in Table 1 indicating contributions of $\sim 4-21 \%$ of the total $\mathrm{C}$ inventory. 


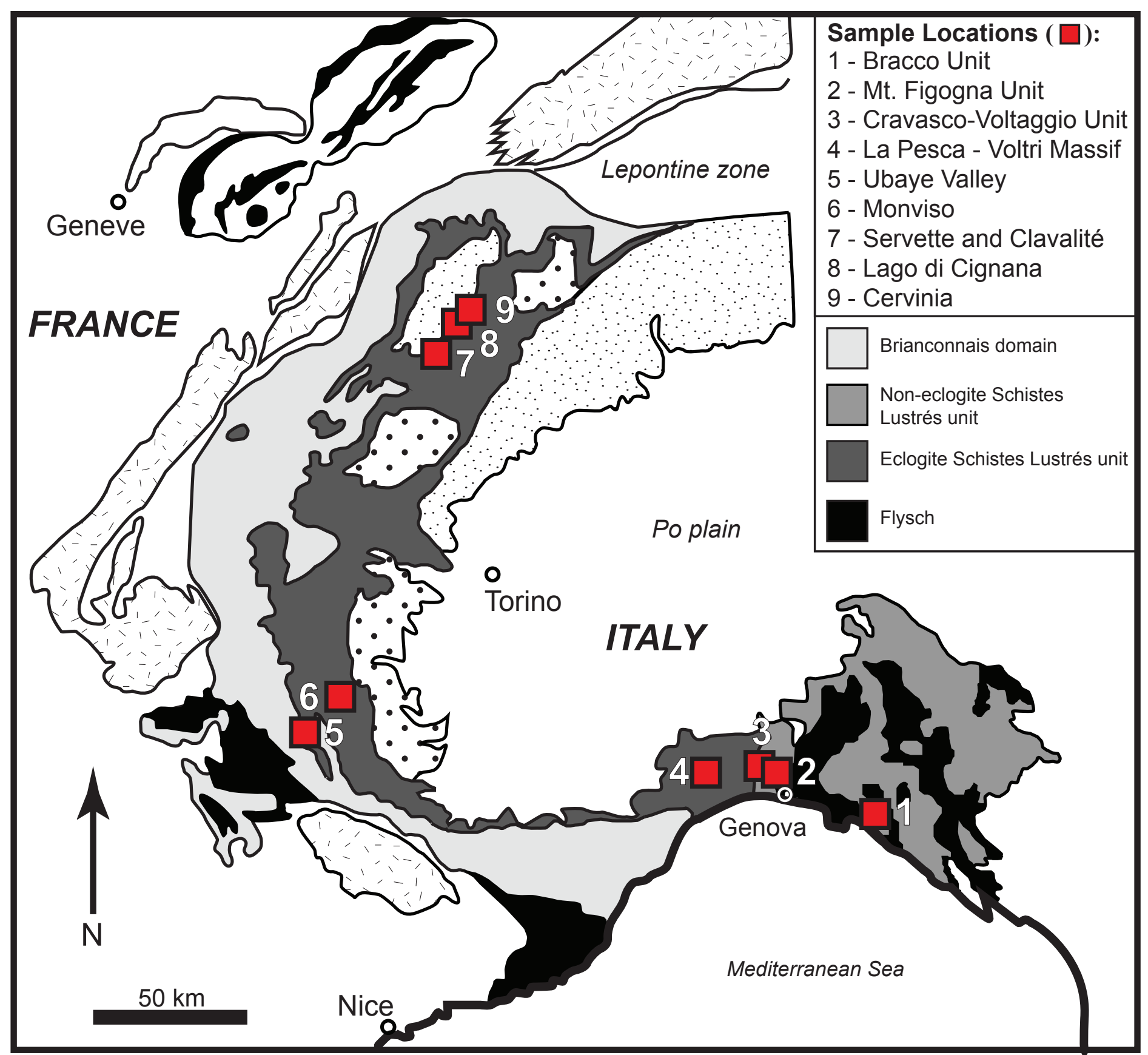




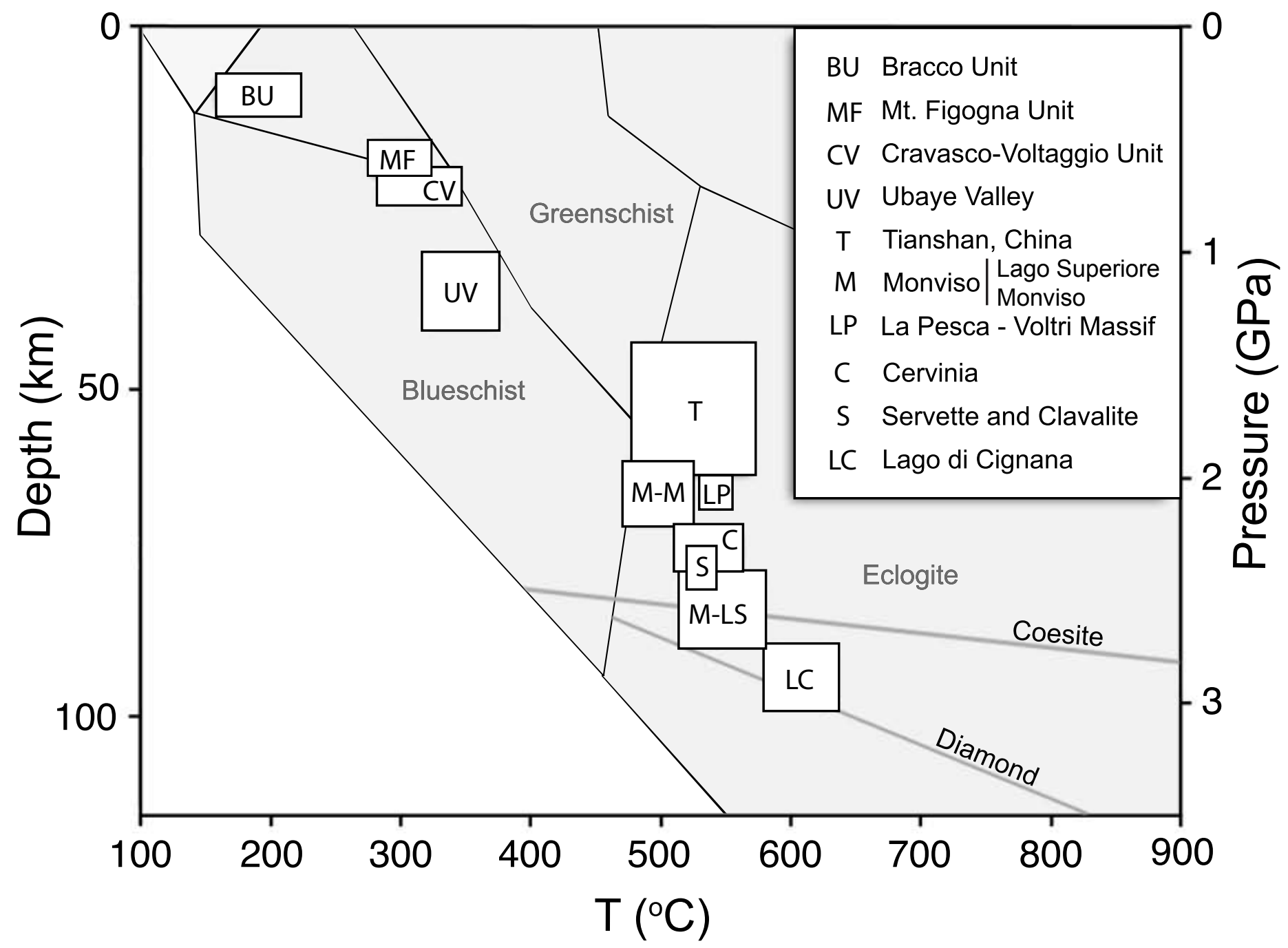

Figure 1b 


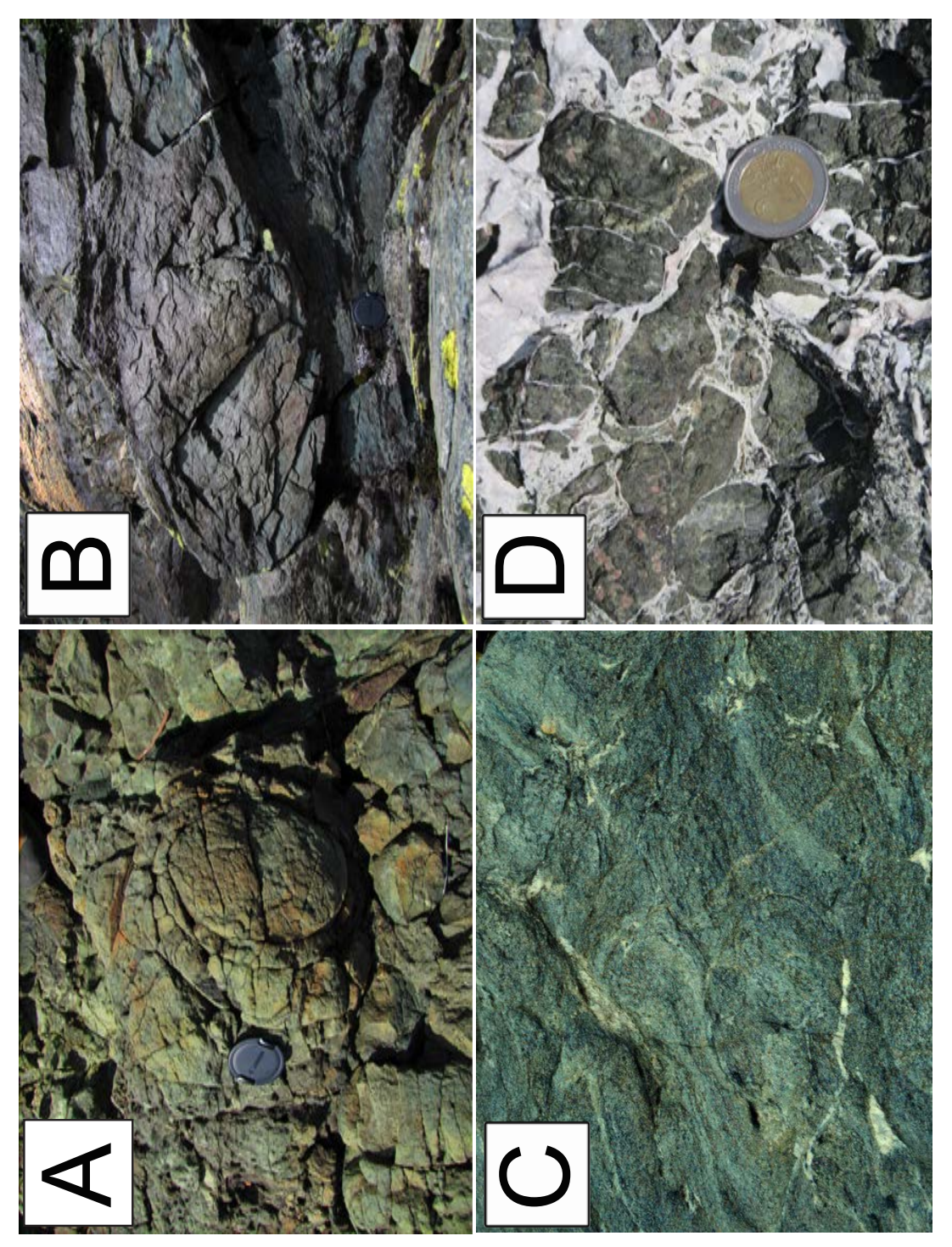

Figure 2

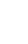




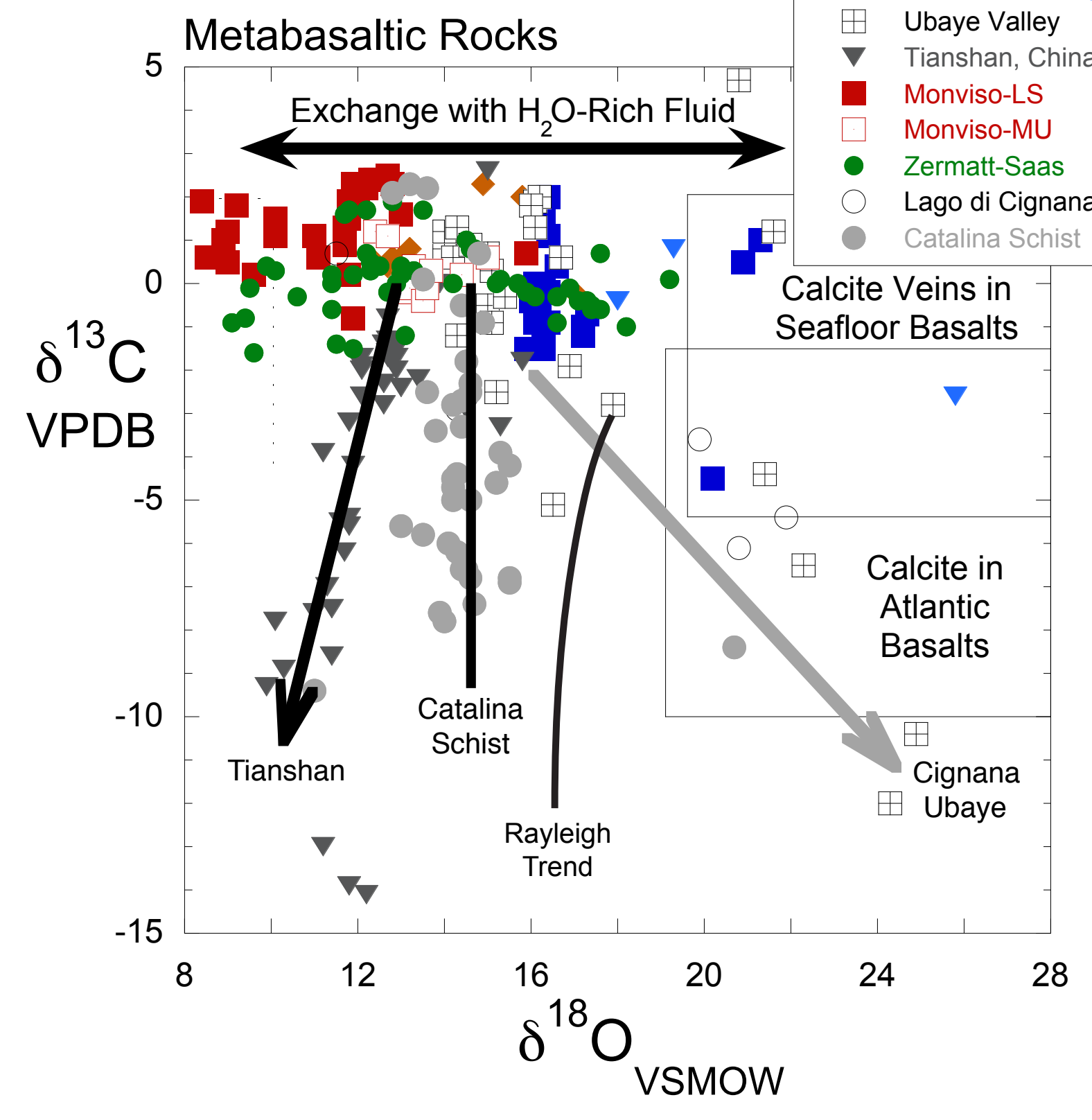

Figure 3

- Bracco Unit

Mt. Fignogna Unit

$\checkmark$ Cravasco-Voltaggio Unit

Ubaye Valley

Tianshan, China

o-LS

Monviso-MU

Zatt-Saas

atalina Schist. 
Figure 4.
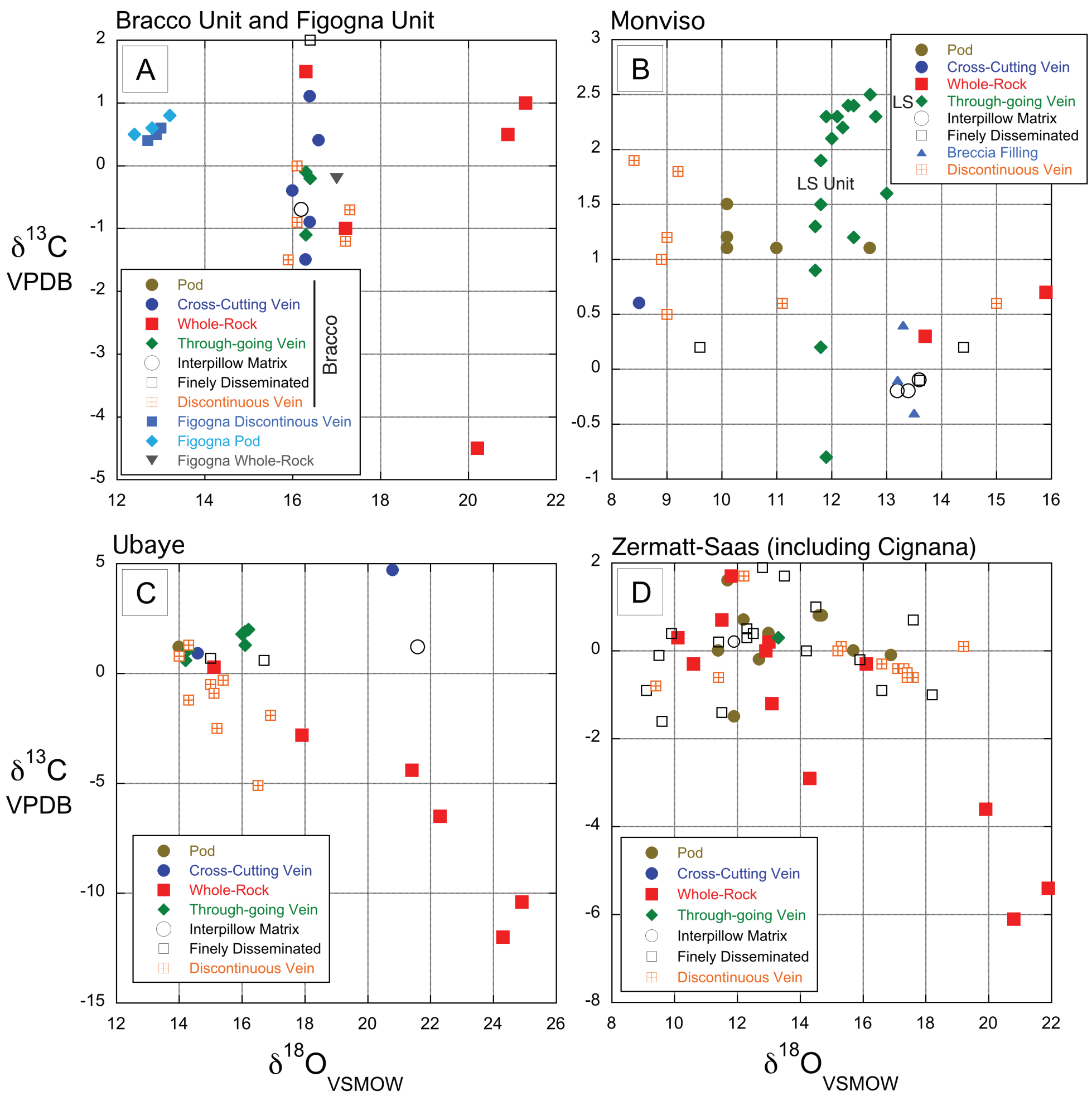


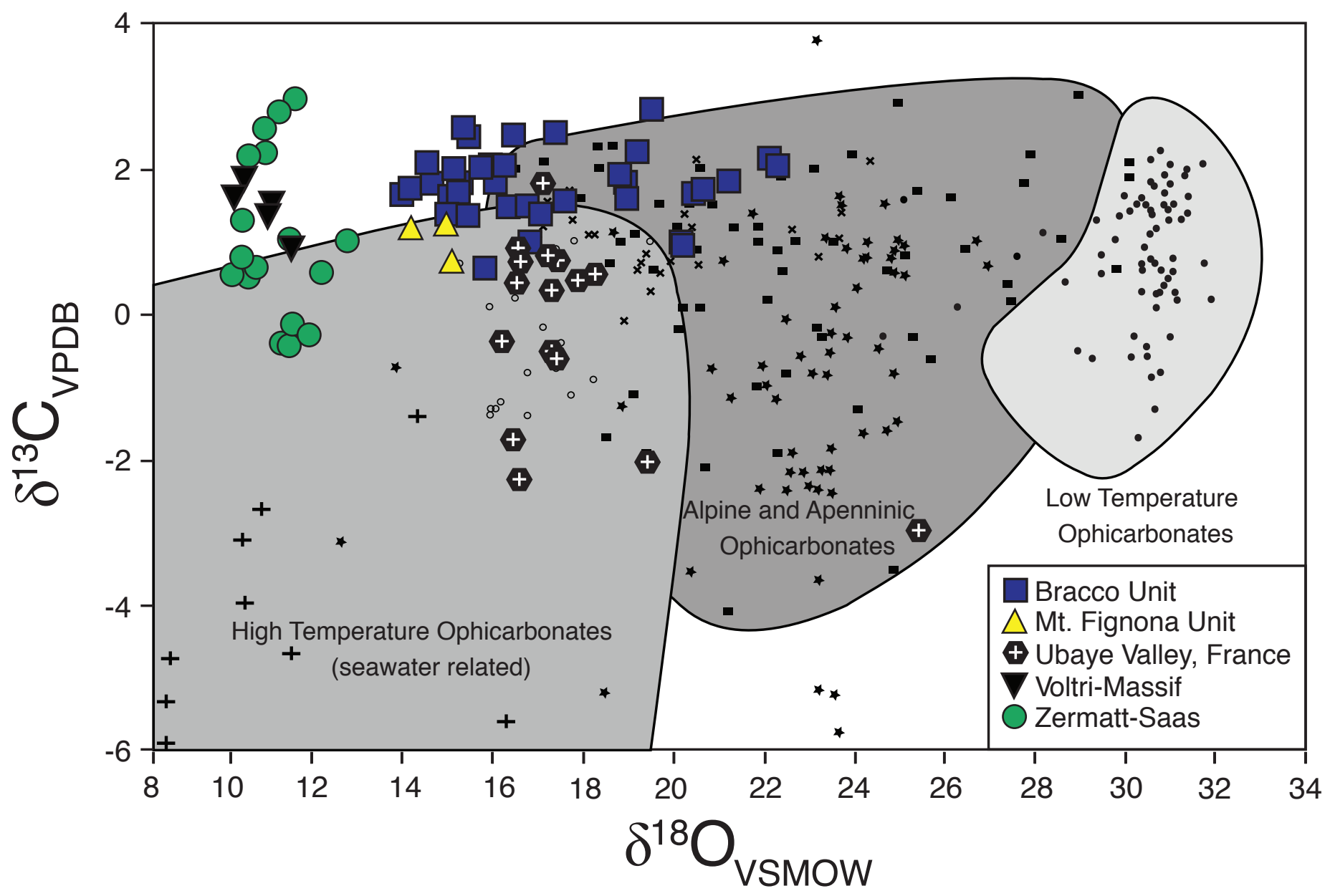

Figure 5 


\section{Fresh Basalt}

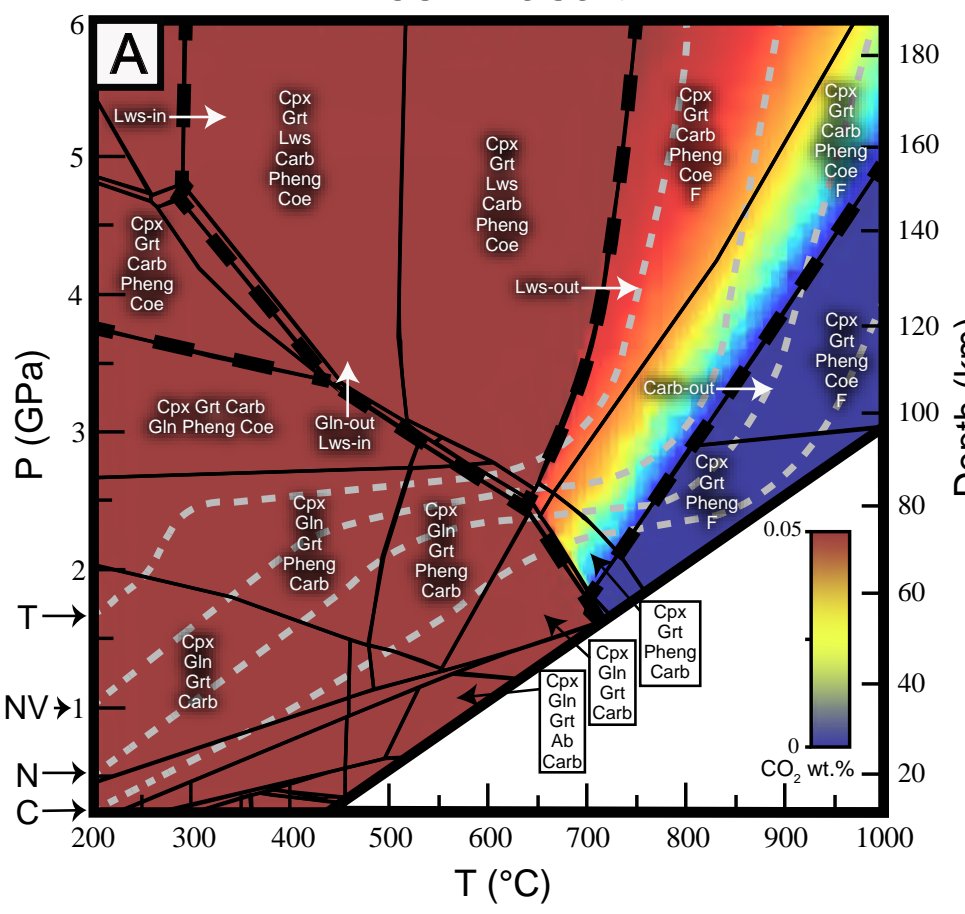

\section{ODP $417 / 418$}

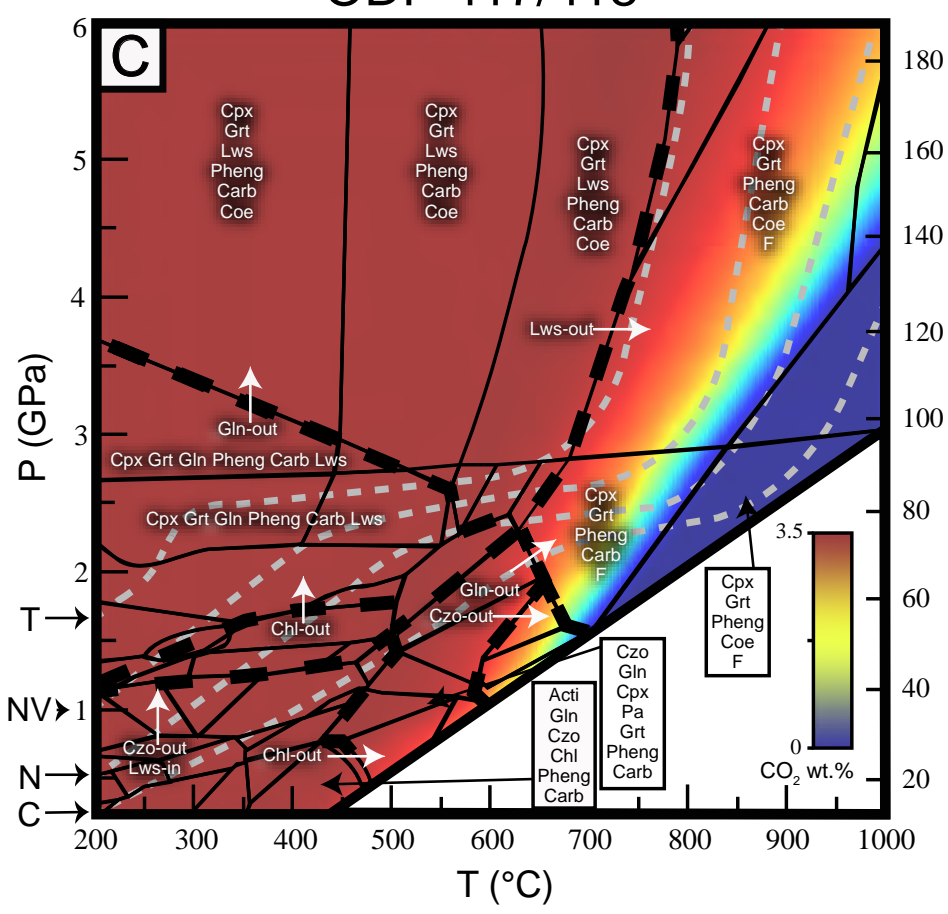

ODP 504a/b

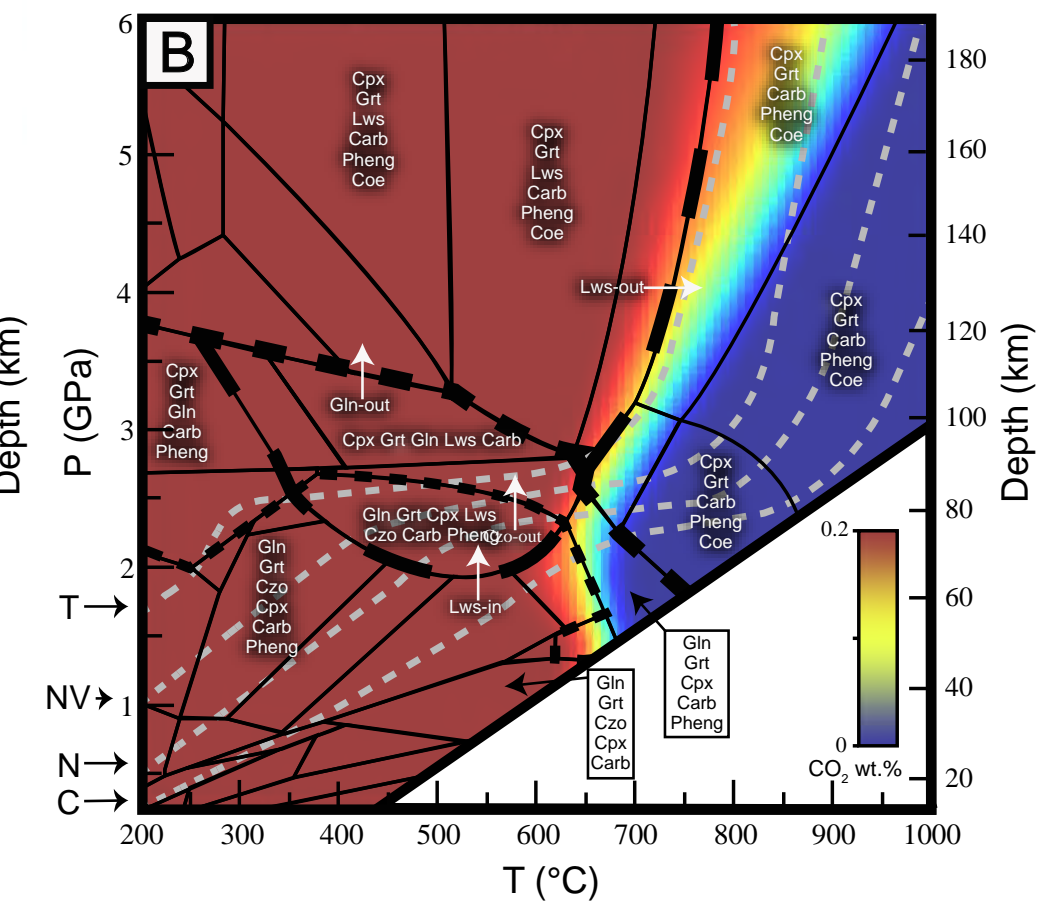

Lago di Cignana

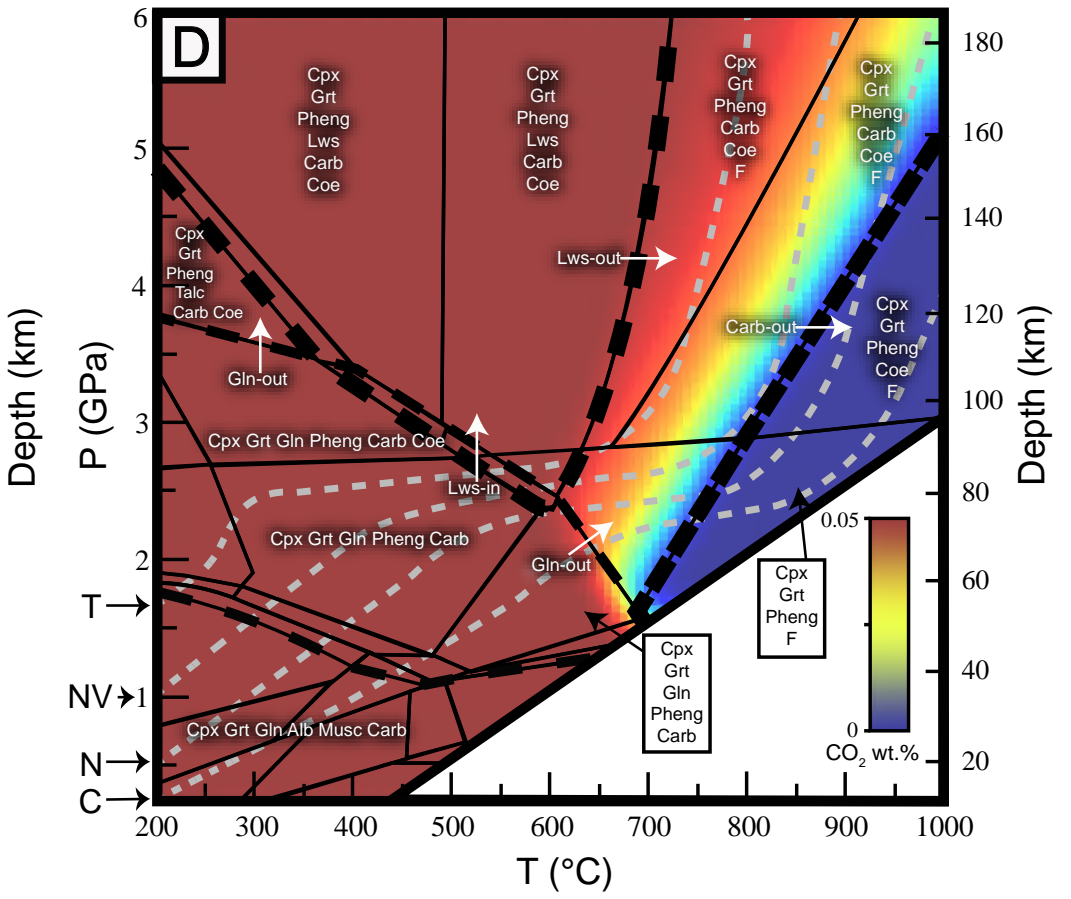

Figure 6 

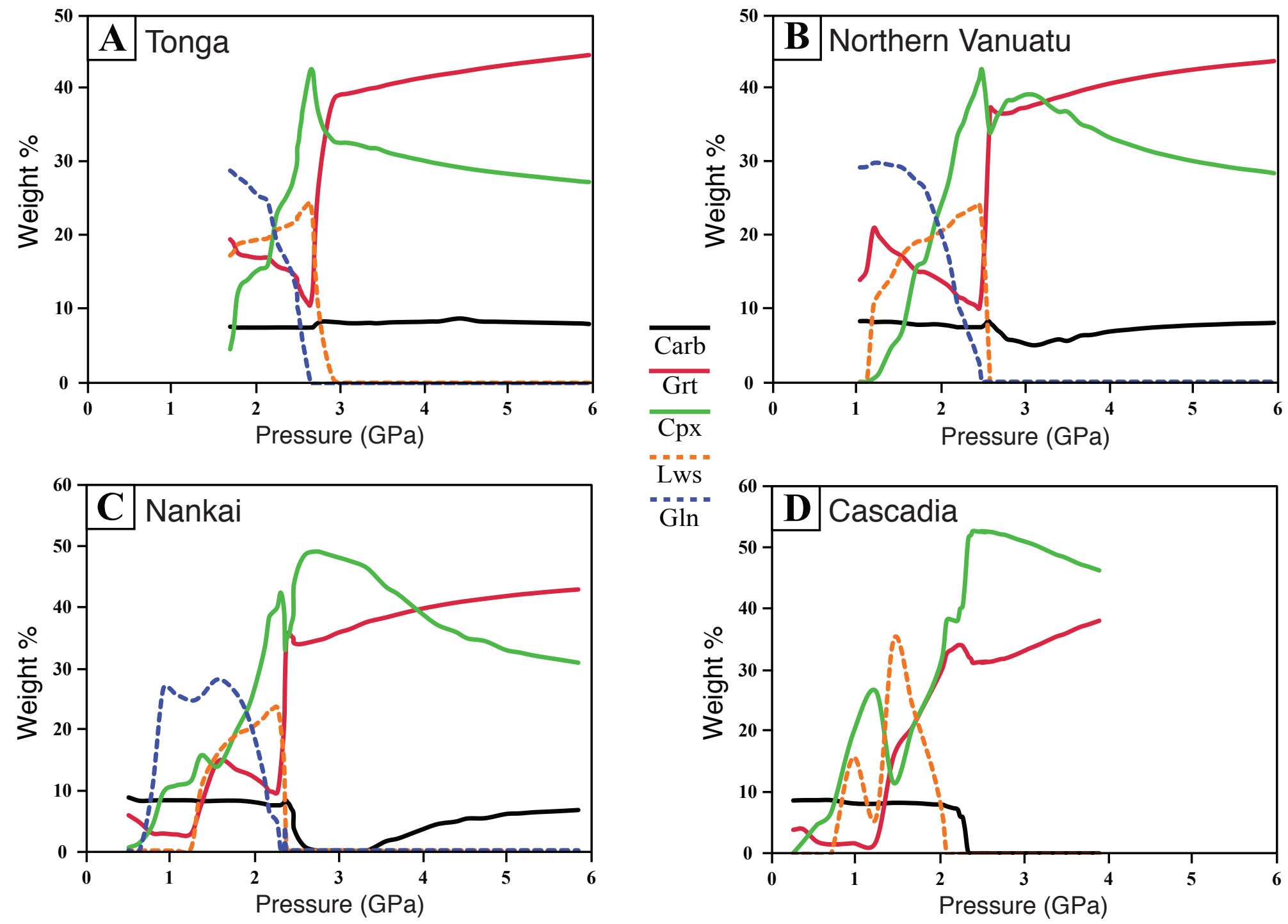

Figure 7 


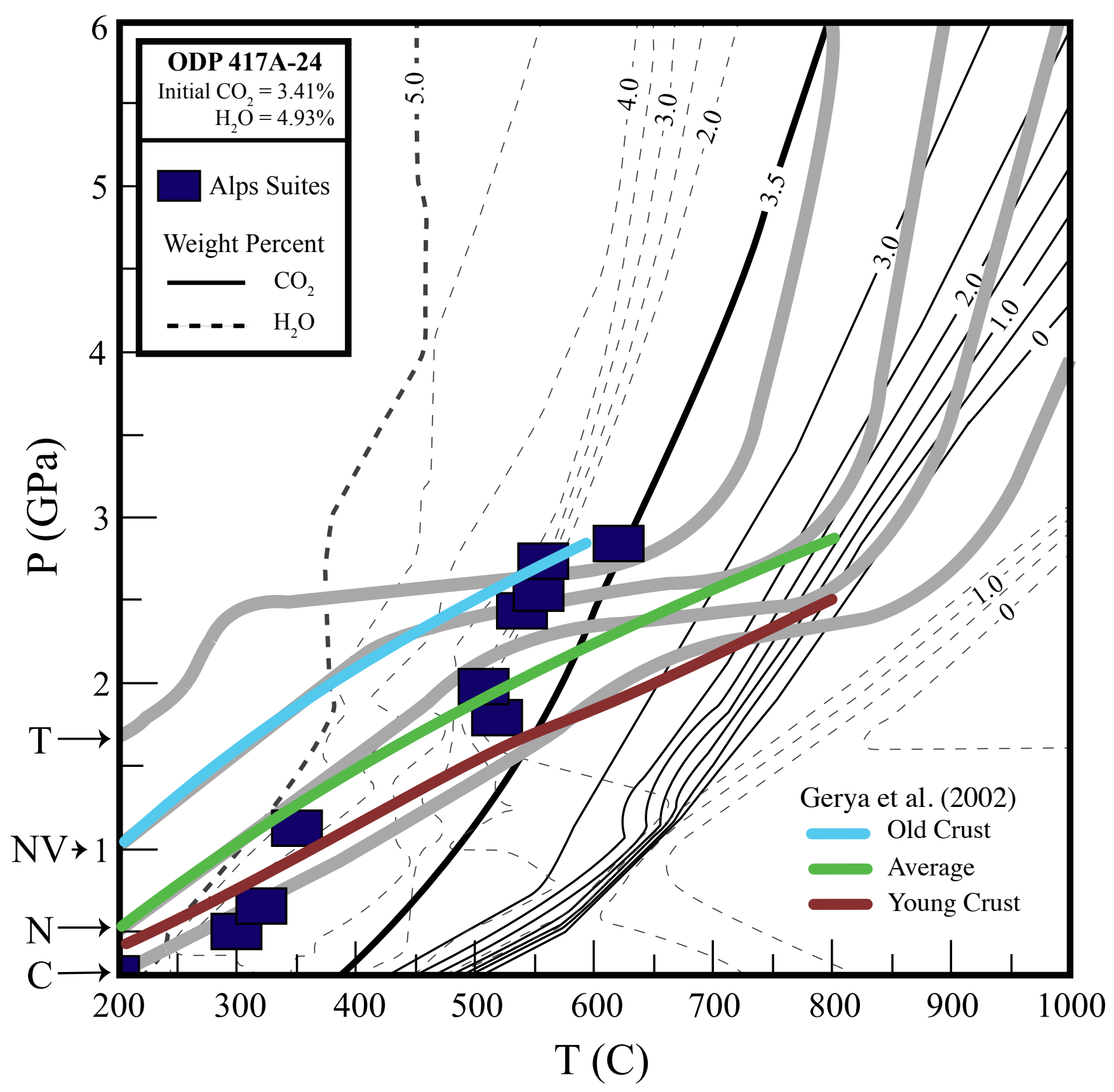

Figure 8a 


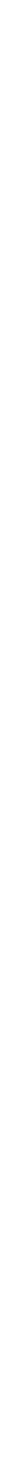

Figure $8 b$ 

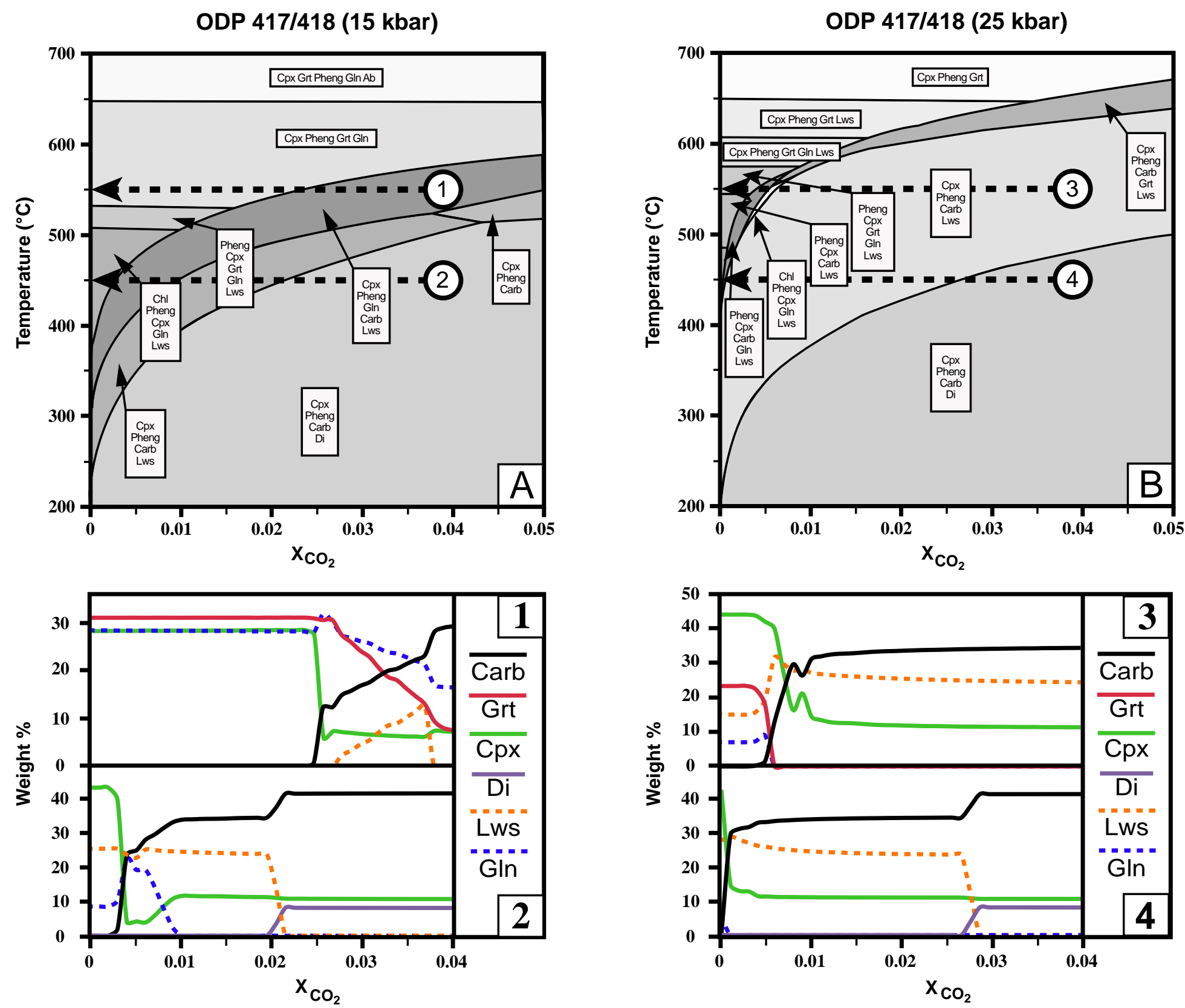

Figure 9 


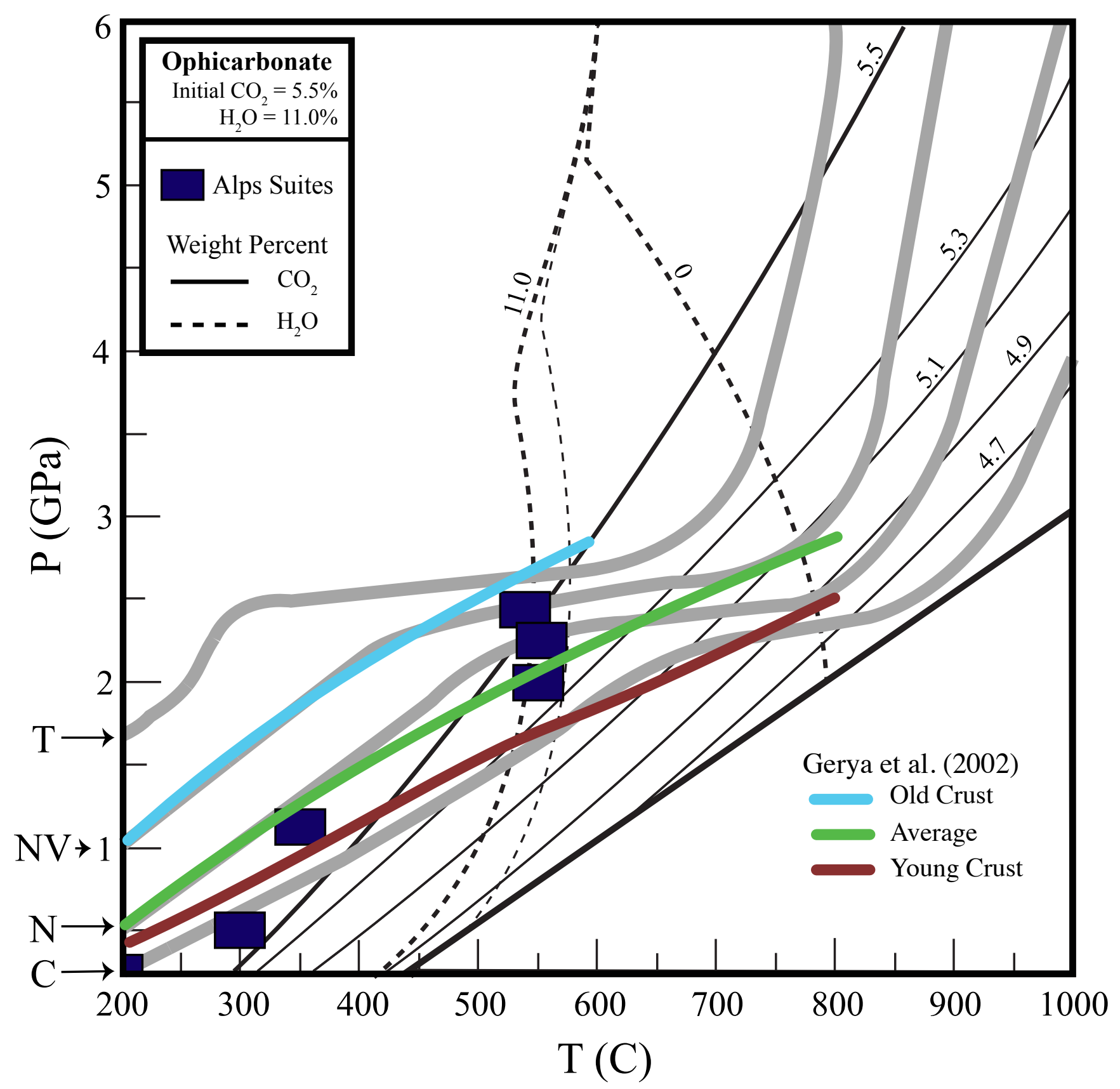

Figure 10 


\begin{tabular}{|c|c|c|c|c|}
\hline \multicolumn{5}{|l|}{ Input (x $\left.10^{12} \mathrm{~mol} \mathrm{C} / \mathrm{yr}\right)$} \\
\hline & Sediments & Basalts & Ultramafics & Total \\
\hline Bebout $(2007,2014)^{*}$ & $0.9-4.8$ & $3.1-4.0$ & $0.4-0.8 * *$ & $4.4-9.6$ \\
\hline Dasgupta (2013) & $1.1-1.4$ & $3.0-5.1$ & $0.4-0.8$ & $4.5-7.3$ \\
\hline Hilton et al. (2002) & 1.34 & 2.12 & \multirow{2}{*}{$0.4-0.8 * *$} & $3.86-4.26$ \\
\hline Jarrard (2003) & 1.2 & 2.27 & & $3.87-4.27$ \\
\hline
\end{tabular}

\begin{tabular}{|l|c|}
\hline \multicolumn{2}{|c|}{ Output (x 10 } \\
\end{tabular}

*The methods for calculating these fluxes are presented in Sadofsky and Bebout (2003).

**from Dasgupta (2013; this flux is added to the sediments and basalts estimates by the other authors)

Table 1. Estimates of $\mathrm{C}$ subduction input and output fluxes from the recent literature. 


\begin{tabular}{|c|c|c|c|c|}
\hline Unit & Location* & $\begin{array}{c}\text { Interpillow } \\
\text { Material }\end{array}$ & \begin{tabular}{|c|} 
Outcrop-scale \\
veins
\end{tabular} & $\begin{array}{c}\text { Hand sample } \\
\text { scale veins }\end{array}$ \\
\hline Bracco Unit & Zerli & & & \\
\hline \multirow{2}{*}{ Bracco Unit } & Foppo & $X X$ & $x$ & $X X$ \\
\hline & Porto Pidocchio & $X X X$ & $X X$ & $\mathrm{XX}$ \\
\hline Mt. Figogna Unit & Figogna & $X X$ & & $x$ \\
\hline Mt. Figogna Unit & Pietra Lavezzara & $\mathrm{XX}$ & & $x$ \\
\hline Cravasco-Voltaggio Unit & Lencisa & $x$ & & \\
\hline Ubaye Valley, France & Pic du Pelvat & $X X X$ & & $\mathrm{XX}$ \\
\hline Lago Superiore Unit & Monviso & $x$ & $x$ & $X X$ \\
\hline Monviso Unit & Monviso & $\mathrm{XX}$ & & \\
\hline Zermatt-Saas Ophiolite & Cervinia & $\mathrm{XXX}$ & & \\
\hline Zermatt-Saas Ophiolite & Servette & $X X$ & & $x$ \\
\hline Zermatt-Saas Ophiolite & Clavalite & $X X$ & & \\
\hline Zermatt-Saas Ophiolite & Lago di Cignana & & & \\
\hline
\end{tabular}

Table 2. Textural settings of carbonate at localities for which $\mathrm{C}$ and $\mathrm{O}$ isotope data are presented in this paper. 
Table 3. Extents of Loss of $\mathrm{CO}_{2}$ in $80-120 \mathrm{~km}$ Depth Range, ClosedSystem Models Only (Figs. 8A, 10; Kerrick and Connolly, 2001a)

\begin{tabular}{|l|c|c|c|c|}
\multicolumn{1}{c}{} & Cascadia & Nankai & N. Vanuatu & Tonga \\
\hline 417A-24 (basalt) & $100 \%$ & 100 & 43 & 7 \\
\hline Ophicarbonate & 15 & 13 & 7 & 3 \\
\hline
\end{tabular}

\section{Sediment Composition} (from Plank and Langmuir, 1998)

\begin{tabular}{|l|c|c|c|c|}
\hline GLOSS & 100 & 100 & 100 & 29 \\
\hline Antilles & 100 & 100 & 100 & 61 \\
\hline Marianas & 17 & 10 & 7 & 2 \\
\hline Vanuatu & 23 & 13 & 6 & 0 \\
\hline
\end{tabular}

